\title{
Incremental amounts of rumen-protected histidine increase plasma and muscle histidine concentrations and milk protein yield in dairy cows fed a metabolizable protein-deficient diet
}

\author{
Y. Zang, ${ }^{1}$ L. H. P. Silva, ${ }^{1}$ M. Ghelichkhan, ${ }^{1}$ M. Miura, ${ }^{3}$ N. L. Whitehouse, ${ }^{1}$ M. L. Chizzotti, ${ }^{2}$ and A. F. Brito ${ }^{1 *}$ \\ ${ }^{1}$ Department of Agriculture, Nutrition, and Food Systems, University of New Hampshire, Durham 03824 \\ ${ }^{2}$ Department of Animal Sciences, Universidade Federal de Viçosa, MG, Brazil 36570-900 \\ ${ }^{3}$ Ajinomoto Co. Inc., Kawasaki-shi, Japan 210-8681
}

\section{ABSTRACT}

The dairy industry can benefit from low crude protein (CP) diets due to reduced $\mathrm{N}$ excretion, but shortages of Met, Lys, and His may limit milk protein synthesis. We studied the effect of incremental amounts of rumen-protected (RP)-His on plasma and muscle AA profile, nutrient utilization, and yields of milk and milk true protein in dairy cows. Eight multiparous Holstein cows $(130 \pm 30 \mathrm{~d}$ in milk) were randomly assigned to treatment sequences in a replicated $4 \times 4$ Latin square design with 28-d experimental periods. Treatments included a basal diet composed (dry matter basis) of $50 \%$ corn silage, $15 \%$ haylage, and 35\% concentrate supplemented with $0,82,164$, and $246 \mathrm{~g} / \mathrm{d}$ of RP-His and $11 \mathrm{~g} / \mathrm{d}$ of RP-Met. Milk, plasma, and muscle samples were collected weekly or every other week during all 4 periods, whereas spot urine and fecal grab samples were taken only in wk 4 of each period. Data were analyzed individually by week using linear, quadratic, and cubic orthogonal polynomials and repeated measures. Plasma His increased linearly with RP-His during wk 1 (30.3 to $57.2 \mu M)$ to wk $4(33.2$ to $63.1 \mu M)$. Plasma carnosine increased linearly with supplemental RP-His except in wk 2. No treatment effect was observed for plasma 3-methylhistidine except a quadratic effect in wk 3 . Inclusion of RP-His showed linear effects on muscle His in wk $2(20.1$ to $32.5 \mu M)$ and 4 (20.3 to $35.5 \mu M$ ). Whereas muscle anserine and carnosine concentrations were not affected by treatments in wk 4, anserine responded quadratically and carnosine showed a trend for a quadratic response to RP-His in wk 2. During wk 4 , treatments did not affect urinary excretion of total purine derivatives, as well as dry matter intake and milk concentrations of fat and true protein. In contrast,

Received October 1, 2018.

Accepted January 18, 2019.

*Corresponding author: andre.brito@unh.edu milk yield tended to increase linearly (31.2 to 32.7 $\mathrm{kg} / \mathrm{d}$ ) and milk true protein yield responded linearly (0.93 to $0.98 \mathrm{~kg} / \mathrm{d})$ and tended to increase quadratically to RP-His supplementation in wk 4. Also, milk urea-N (11.7 to $12.9 \mathrm{mg} / \mathrm{dL}$ ) and urinary excretion of urea-N (23.7 to $27.0 \%$ of $\mathrm{N}$ intake) increased linearly with feeding RP-His in wk 4. Overall, RP-His was effective to enhance plasma and muscle concentrations of His and milk protein synthesis. Elevated milk urea-N and urinary excretion of urea- $\mathrm{N}$ suggest that plasma His may have exceeded the requirement with excess $\mathrm{N}$ converted to urea in the liver. Future research is needed to determine the bioavailability of RP-His supplements to improve the accuracy of diet formulation for AA.

Key words: low crude protein diet, nitrogen efficiency, metabolizable protein, rumen-protected amino acid

\section{INTRODUCTION}

According to the NRC (2001), maximum yields of milk and milk protein were obtained at 22 to $23 \%$ dietary $\mathrm{CP}$ based on regression approaches. However, such high-CP diets have been shown to reduce milk $\mathrm{N}$ efficiency (i.e., milk $\mathrm{N} / \mathrm{N}$ intake), increase environmental $\mathrm{N}$ pollution, and shrink the profit margin of dairy producers due to the high costs of protein sources (Broderick, 2003; Olmos Colmenero and Broderick, 2006). Feeding low-CP diets improved milk N efficiency and reduced urinary $\mathrm{N}$ excretion, but also decreased yields of milk and milk true protein (Broderick et al., 2009; Lee et al., 2011), which may be attributed to deficient RDP supply or reduced intake of digestible Lys, Met, and His (dLys, dMet, and dHis) or both. Methionine and Lys are usually co-limiting AA (first or second) in typical US diets (Schwab et al., 1976; NRC, 2001), and His may become the third limiting AA in MP-deficient rations (Lee et al., 2012). One common way to mitigate dietary shortages of Lys, Met, and His is through supplementation of rumen-protected (RP) AA (e.g., Lee et al., 2012; Whitehouse et al., 2017). 
Rumen-protected-AA supplements are characterized by low ruminal degradation and variable intestinal absorption of AA, thus resulting in different amounts of Lys, Met, and His transported into the blood (Lee et al., 2012; Whitehouse et al., 2017; Zang et al., 2017). Doepel and Lapierre (2010) suggested that increased plasma concentrations of EAA stimulate their uptake by the mammary gland, which in turn improved yields of milk and milk protein. While supplementation of MP-deficient diets with RP-Met and RP-Lys has steadily elevated the concentrations of these 2 EAA in plasma of lactating dairy cows, a similar consistent response has not been observed with feeding RP-His based on previous research (Lee et al., 2012; Giallongo et al., 2015, 2016). For instance, Lee et al. (2012) and Giallongo et al. (2016) observed that supplementing $120 \mathrm{~g} / \mathrm{d}$ of RP-His to $10 \% \mathrm{MP}$-deficient diets increased plasma His concentration by an average of $64 \%$ in two 10 -wk randomized complete block design studies. However, plasma concentration of His did not change when adding $50 \mathrm{~g} / \mathrm{d}$ of RP-His to a $5 \%$ MP-deficient diet in another 10 -wk randomized complete block design experiment (Giallongo et al., 2015). These inconsistent results may be attributed to the use of labile pools of His including intramuscular carnosine ( $\beta$-alanyl-L-His) and anserine ( $\beta$-alanyl- $N$-methyl-His) and blood hemoglobin during short-term His deficiency (Lapierre et al., 2008).

In recent years, a growing number of studies have been conducted to explore the metabolism of endogenous His reserves in lactating dairy cows. Lapierre et al. (2014) reported that muscle carnosine and anserine showed quadratic responses to abomasal infusions of His ranging from 0 to $22.8 \mathrm{~g} / \mathrm{d}$. In contrast, muscle carnosine and anserine were not different between a His-deficient and a His-adequate diet (Giallongo et al., 2015). Blood hemoglobin was not affected by infusing His abomasally (Lapierre et al., 2014) or feeding RP-His to lactating dairy cows (Giallongo et al., 2016). However, information is lacking regarding the metabolism of endogenous His pools in dairy cows fed MP-deficient diets supplemented with varying levels of RP-His. Our central hypothesis is that plasma and muscle concentrations of His would respond linearly to increasing amounts of RP-His fed to lactating dairy cows. The primary objective of our study was to investigate the effect of incremental amounts of RP-His on plasma and muscle AA profile, nutrient utilization, and yields of milk and milk true protein in mid-lactation Holstein cows. A secondary objective was to assess the temporal changes of His and His-containing metabolites by collecting blood samples weekly and conducting muscle biopsies every other week during a RP-His dose-response study in a Latin square design.

\section{MATERIALS AND METHODS}

All experimental procedures were approved by the Institutional Animal Care and Use Committee (protocol no. 170202) of the University of New Hampshire (Durham). The experiment was conducted at the University of New Hampshire Fairchild Dairy Teaching and Research Center (Durham) from March to July 2017.

\section{Cows, Experimental Design, and Treatments}

Eight multiparous Holstein cows averaging (mean \pm SD) $130 \pm 30$ DIM, $42 \pm 2 \mathrm{~kg} / \mathrm{d}$ of milk, and $717 \pm$ $53 \mathrm{~kg}$ of BW in the beginning of the study were used in a replicated $4 \times 4$ Latin square design with 28 -d experimental periods. Cows were blocked by DIM and milk yield, and within each block, randomly assigned to treatment sequences. Squares were balanced for potential first-order carryover effects in subsequent periods as each treatment immediately preceded and followed every other exactly once in each square (Williams, 1949; Kim and Stein, 2009). Animals were housed in a tiestall barn equipped with water bowels for free access to water and feed tubes for individual intake measurements. Dietary ingredients were mixed and offered as TMR twice daily at 0600 and $1700 \mathrm{~h}$ using a Super Data Ranger mixer (American Calan Inc., Northwood, $\mathrm{NH})$. Orts were collected and weighed once daily before the afternoon feeding. Feed offered was adjusted daily to achieve 5 to $10 \%$ orts and cows were milked twice a day at 0530 and $1630 \mathrm{~h}$. Feed intake and milk yield were recorded throughout the experiment. Cows were weighed (Northeast Scale Co., Hooksett, NH) immediately after the afternoon milking during 3 consecutive days before the beginning of the study and at the end of each period to compute BW change. Body condition score was determined by 3 trained individuals before the beginning of the experiment and on the last day of each period following the procedures outlined by Wildman et al. (1982).

During the 2-wk covariate period, all cows received the same diet fed as TMR (17.2\% CP, $28.1 \% \mathrm{NDF}$, and $4.2 \%$ ether extract) consisting of (DM basis): $44.7 \%$ corn silage, $12.6 \%$ mixed mostly grass-legume haylage, and $42.7 \%$ concentrate. The covariate period was used for reduce animal variation in Latin square designs as reported by Whitehouse et al. (2017). Milk samples were collected on d 13 and 14 of the covariate period, and blood (coccygeal vessels) and muscle (longissimus dorsi) samples were taken on d 14 .

Treatments included a basal diet supplemented with $0,82,164$, and $246 \mathrm{~g} / \mathrm{d}$ of RP-His $(0,5,10$, and $15 \mathrm{~g} / \mathrm{d}$ of dHis, respectively) in addition to $11 \mathrm{~g} / \mathrm{d}$ of RP-Met $(6.6 \mathrm{~g} / \mathrm{d}$ of dMet); the RP-AA supplements were top- 
dressed on top of the TMR. The basal diet consisted of (DM basis): $50 \%$ corn silage, $15 \%$ mixed mostly grass-legume haylage, and $35 \%$ concentrate. It was formulated using the NRC (2001) to meet $100 \% \mathrm{NE}_{\mathrm{L}}$ and $82.5 \%$ MP requirements for a dairy cow averaging 680 $\mathrm{kg}$ of BW, 130 DIM, $42 \mathrm{~kg} / \mathrm{d}$ of milk, $3.70 \%$ of milk fat, and $2.75 \%$ of milk true protein. According to the NRC (2001), dietary His represented 2.06, 2.28, 2.52, and $2.75 \%$ of MP supply, respectively. The RP-His supplement used is a prototype product (Ajinomoto Co. Inc., Kawasaki-shi, Japan) containing $44 \%$ of His with $14 \%$ bioavailability (A. Haruno, senior researcher at Ajinomoto Co. Inc.; personal communication). Smartamine M (Adisseo USA Inc., Alpharetta, GA), which contains $75 \%$ DL-Met and $80 \%$ bioavailability (Graulet et al., 2005), was used as the RP-Met supplement.

\section{Feed Sampling and Analyses}

Corn silage, mixed mostly grass-legume haylage, TMR, and ort samples were collected twice weekly and composited by week. Samples of concentrates (i.e., ground corn, beet pulp, soybean meal, steam-flaked corn, canola meal, liquid molasses, and corn dried distillers grains with solubles) were collected by Poulin Grain Inc. (Newport, VT) every time a new batch of grain mix was shipped. All feed samples were equally divided into 2 subsamples, with the first set dried $\left(55^{\circ} \mathrm{C}\right.$, $48 \mathrm{~h}$ ) in a forced-air oven (VWR Scientific, Radnor, $\mathrm{PA})$ for determination of DM to adjust the TMR on an as-fed basis and to calculate DMI. The second set was lyophilized for $48 \mathrm{~h}$ (Labconco Inc., Kansas City, $\mathrm{MO}$ ), composited by period, ground with a Wiley mill (A. H. Thomas Co., Swedesboro, NJ) to pass through a 1-mm screen, and stored in air-tight glass jars until nutritional analysis.

Lyophilized and ground $(1 \mathrm{~mm})$ samples of dietary ingredients were shipped to Dairy One Cooperative Inc. (Ithaca, NY) and analyzed for DM, CP, soluble protein, aNDFom, ADF, NDIN, ADIN, ADL, starch, ethanol soluble carbohydrates, ether extract, and ash using the procedures reported by Pereira et al. (2017) and Ghedini et al. (2018). Individual minerals (Ca, P, Mg, K, Na, $\mathrm{S}, \mathrm{Fe}, \mathrm{Zn}, \mathrm{Cu}, \mathrm{Mn}$, and $\mathrm{Mo}$ ) were also analyzed with the procedures mentioned by Ghedini et al. (2018), whereas $\mathrm{Cl}$ ion was determined by a Brinkmann Metrohm 716 Titrino Titration Unit with a silver electrode (Metrohm application bulletin no. 130, Metrohm Ltd., Herisau, Switzerland).

Lyophilized and ground $(1 \mathrm{~mm})$ samples of dietary ingredients were further ground (Wiley mill, A. H. Thomas Co.) to pass through a $0.5-\mathrm{mm}$ screen and used for determination of AA by cation exchange chro-
matography-HPLC coupled with postcolumn ninhydrin derivatization with norleucine as the internal standard (method 982.30; AOAC International, 2016; University of Missouri Agricultural Experiment Station Chemical Laboratory, Columbia). Tryptophan was determined after alkaline hydrolysis and sulfur AA were analyzed after performic acid oxidation (method 988.15; AOAC International, 2016). Additionally, TMR and orts were analyzed for CP, NDF, ADF, and ash at Dairy One Cooperative Inc. laboratory.

\section{Blood and Muscle Sampling and Analyses}

Blood samples were collected into vacutainer EDTA tubes (Monoject, Mansfield, MA) via the coccygeal vein or artery approximately $4 \mathrm{~h}$ after the morning feeding on $\mathrm{d} 7$ of wk 1 to 4 of each experimental period. For plasma collection, tubes were immediately placed in a chill bucket with beads (Chemglass Life Sciences, Vineland, NJ) and transported to the laboratory for centrifugation $\left(2,155 \times g, 20 \mathrm{~min}, 4^{\circ} \mathrm{C}\right)$ using an Eppendorf centrifuge (model 5810, Eppendorf, Hamburg, Germany). Plasma samples were used to determine the profile of AA, His-containing metabolites, and urea-N (PUN) at Ajinomoto Co. Inc. using a High-Speed AA analyzer L-8900 (Hitachi High-Technologies Co., Tokyo, Japan) following the procedures stated by the manufacturer (http://www.hitachi-hta.com/sites/default/files/ literature/L-8900\%20Brochure.pdf). Codified plasma samples were sent to Ajinomoto Co. Inc. to preserve the identity of treatments.

Biopsies were performed by sampling the longissimus dorsi muscle on d 7 of wk 2 and 4 of each experimental period. Cows were moved out of their stalls, brought to a surgical room, and immobilized in a hoof trimming chute. The surgical area (between the 12th and 13 th transverse processes) was clipped and sanitized by scrubbing with povidone surgical scrub and $91 \%$ isopropyl alcohol (vol/vol). Next, cows were anesthetized by injecting $4 \mathrm{~mL}$ of $2 \%$ lidocaine hydrochloride (wt/ vol) subcutaneously down to the musculature on either side of the biopsy site ( $8 \mathrm{~mL}$ total). A 2.5 -cm incision was made through the skin with a sterile scalpel blade to expose the muscle and obtain a sample of tissue using an 8-mm Baker's dermal punch (Patterson Veterinary Supply, Devens, MA). Samples ( 1.0 g/cow) were immediately placed in a container with dry ice, transported to the laboratory, and stored at $-80^{\circ} \mathrm{C}$ until analysis. The biopsy sites were closed with nonabsorbable sutures (Braunamid, Patterson Veterinary Supply) and monitored closely to avoid infection until sutures were removed within 2 wk. After thawing at room temperature, muscle tissues were homogenized 
with a tissue homogenizer (Omni International Inc., Kennesaw, GA), deproteinized with $0.61 N$ trichloroacetic acid, and finally treated with n-hexane to extract AA and dipeptides. Sample extracts were shipped codified to Ajinomoto Co. Inc. and analyzed for carnosine, anserine, and AA profile using a High-Speed AA analyzer L-8900 as reported previously.

\section{Fecal and Urinary Sampling and Analyses}

Fecal grab samples were taken directly from the rectum or during voluntary defecation at 8 time points $(1000,1600$, and $2200 \mathrm{~h}$ on d 25; 0400, 1300, and 1900 $\mathrm{h}$ on d 26; and 0100 and $0800 \mathrm{~h}$ on d 27) in wk 4 of each experimental period. Fecal samples ( $200 \mathrm{~g}$ /sampling) were collected into $100-\mathrm{mL}$ specimen containers and transferred into 4-L storage bags to obtain composited samples by cow per period. Next, samples were dried in a forced-air oven (VWR Scientific) at $55^{\circ} \mathrm{C}$ for approximately $72 \mathrm{~h}$ and ground (Wiley mill, A. H. Thomas Co.) to pass through a 1-mm screen. Fecal samples were analyzed for $\mathrm{DM}, \mathrm{CP}, \mathrm{NDF}, \mathrm{ADF}$, and ash at Dairy One Cooperative Inc. laboratory. Moreover, duplicate samples $(\sim 0.5 \mathrm{~g})$ of feces, dietary ingredients, and TMR were weighed into Ankom F57 bags $(25 \mu \mathrm{m}$ pore size, Ankom Technology, Macedon, NY), placed in larger laundry nylon bags, and inserted in the rumen of 2 ruminally cannulated lactating Holstein cows for 12 d. After removal from the rumen, bags were rinsed with tap water and analyzed in-house for ADF using an Ankom $^{2000}$ fiber analyzer (Ankom Technology). Indigestible ADF (iADF) obtained from TMR and feces was used as the internal marker to estimate fecal output of DM and apparent total-tract digestibility of nutrients (Cochran et al., 1986; Huhtanen et al., 1994).

Spot urine samples were collected concurrently with fecal samples into 100-mL specimen containers through stimulation of the pudendal nerve by massaging the area below the vulva or during voluntary urination in wk 4 of each experimental period. After each sampling, $1 \mathrm{~mL}$ of urine was pipetted into $50-\mathrm{mL}$ centrifuge tubes containing $32 \mathrm{~mL}$ of $0.072 \mathrm{~N} \mathrm{H}_{2} \mathrm{SO}_{4}$ to obtain composited urine samples by cow per period. Urine samples were stored at $-20^{\circ} \mathrm{C}$ before analyses of nitrogenous compounds. After thawing at room temperature, samples were analyzed for concentrations of creatinine (assay kit no. 500701, Cayman Chemical Co., Ann Arbor, MI) using a chromate microplate reader set at a wavelength of $492 \mathrm{~nm}$ (Awareness Technology Inc., Palm City, FL), allantoin (Chen et al., 1992), uric acid (assay kit no. 1045-225, Stanbio Laboratory, Boerne, TX), urea-N (diacetyl-monoxime method of Rosenthal, 1955), and total-N (micro-Kjeldahl analysis, AOAC, 1990; Dairy
One Cooperative Inc.). Allantoin, uric acid, and urea$\mathrm{N}$ were read at wavelengths of 540,522 , and $520 \mathrm{~nm}$, respectively, on a UV/visible spectrophotometer (Beckman Coulter Inc., Pasadena, CA). Daily urine volume was estimated from urinary creatinine concentration assuming a constant creatinine excretion rate of $29 \mathrm{mg} /$ $\mathrm{kg}$ of BW (Valadares et al., 1999). Urinary excretion of urea-N, total-N, allantoin, uric acid, and purine derivatives (allantoin + uric acid) was calculated by multiplying the concentration of each of these metabolites by the urinary volume.

\section{Milk Sampling and Analyses}

Milk samples were collected using automatic samplers during 4 consecutive milkings starting in the afternoon milking of $\mathrm{d} 6$ in wk 1 to 4 of each experimental period. Milk samples were transferred into tubes preserved with 2-bromo-2-nitropropan-1,3 diol (Broad Spectrum Microtabs II, Advanced Instruments Inc., Norwood, MA), pooled by cow proportionally to the morning and afternoon milk weights, and stored at $4^{\circ} \mathrm{C}$ until analysis. Milk samples were shipped to Dairy One Cooperative Inc. and analyzed for concentrations of fat, true protein, lactose, and MUN by Fourier transform infrared spectroscopy using a MilkoScan FT+ (Foss Inc., Hillerød, Denmark).

\section{Statistical Analyses}

The present study was conducted as a replicated 4 $\times 4$ Latin square design with milk, plasma, and muscle samples collected weekly or every other week. This sampling regimen allowed the statistical analyses to be conducted using data from individual week of each period to test linear, quadratic, and cubic effects in response to incremental amounts of RP-His supplementation as follows: wk 1 (d 1 to 7 of periods 1 to 4 ), wk 2 (d 8 to 14 of periods 1 to 4 ), wk 3 (d 15 to 21 of periods 1 to 4 ), and wk 4 (d 22 to 28 of periods 1 to 4 ). In addition, repeated measures were used to evaluate the temporal changes of plasma and muscle AA concentrations in response to RP-His supplementation. Data on apparent total-tract digestibility of nutrients and urinary $\mathrm{N}$ excretion are from wk 4 of each experimental period because no collections of spot urine and fecal grab samples were conducted during wk 1 to 3 .

Data (i.e., plasma and muscle AA concentrations, DMI, yields of milk and milk components) were analyzed as a replicated $4 \times 4$ Latin square design using the MIXED procedure of SAS (SAS version 9.4, SAS Institute Inc., Cary, NC) according to the following model: 


$$
\begin{gathered}
\mathrm{Y}_{\mathrm{ijkl}=\mu+} \mathrm{S}_{\mathrm{i}}+\mathrm{C}_{\mathrm{j}(\mathrm{i})}+\mathrm{P}_{\mathrm{k}}+\mathrm{T}_{1}+\mathrm{S}_{\mathrm{i}} \times \mathrm{T}_{1} \\
+\beta \operatorname{Cov}_{\mathrm{ijkl}}+\mathrm{e}_{\mathrm{ijk} \mathrm{kl}},
\end{gathered}
$$

where $\mathrm{Y}_{\mathrm{ijkl}}=$ dependent variable, $\mu=$ overall mean, $\mathrm{S}_{\mathrm{i}}=$ fixed effect of square ( $\mathrm{i}=1$ to 2$), \mathrm{C}_{\mathrm{j}(\mathrm{i})}=$ random effect of cow nested within square, $\mathrm{P}_{\mathrm{k}}=$ fixed effect of period ( $\mathrm{k}=1$ to 4$), \mathrm{T}_{1}=$ fixed effect of treatment (l=1 to 4$), S_{i} \times T_{1}=$ interaction between ith square and lth treatment, $\beta=$ regression coefficient of the covariate term $\operatorname{Cov}_{\mathrm{ijk}}, \mathrm{Cov}_{\mathrm{ijkl}}=$ covariate variable for the jth cow within the ith square of the lth treatment in the kth period, and $e_{\mathrm{ijk}}=$ residual error. The covariate term was removed from the statistical model when $P$ $>0.25$. Apparent total-tract digestibility of nutrients and urinary excretion of nitrogenous metabolites were analyzed with the same model presented above without the covariate term. Orthogonal polynomials were used to test linear, quadratic, and cubic effects in response to incremental amounts of RP-His supplementation. All data except digestibility of nutrients and urinary $\mathrm{N}$ excretion were reported as covariate-adjusted LSM \pm SEM. Significance was declared at $P \leq 0.05$ and trends at $0.05<P \leq 0.10$.

Plasma and muscle concentrations of His and Hiscontaining metabolites were further analyzed as repeated measures using the MIXED procedure of SAS (SAS version 9.4) according to the following model:

$$
\begin{aligned}
\mathrm{Y}_{\mathrm{ijklm}} & =\mu+\mathrm{S}_{\mathrm{i}}+\mathrm{C}_{\mathrm{j}(\mathrm{i})}+\mathrm{P}_{\mathrm{k}}+\mathrm{T}_{1}+\mathrm{S}_{\mathrm{i}} \times \mathrm{T}_{1}+\mathrm{e} \mathrm{1}_{\mathrm{ijkl}} \\
& +\mathrm{W}_{\mathrm{m}}+\mathrm{T}_{1} \times \mathrm{W}_{\mathrm{m}}+\beta \operatorname{Cov}_{\mathrm{ijk} l m}+\mathrm{e} 2_{\mathrm{ijk} \mathrm{m}}
\end{aligned}
$$

where $\mathrm{Y}_{\mathrm{ijklm}}=$ dependent variable, $\mu=$ overall mean, $\mathrm{S}_{\mathrm{i}}=$ fixed effect of square ( $\mathrm{i}=1$ to 2$), \mathrm{C}_{\mathrm{j}(\mathrm{i})}=$ random effect of cow nested within square, $\mathrm{P}_{\mathrm{k}}=$ fixed effect of period ( $\mathrm{k}=1$ to 4$), \mathrm{T}_{1}=$ fixed effect of treatment $(\mathrm{l}=1$ to 4$), \mathrm{S}_{\mathrm{i}} \times \mathrm{T}_{1}=$ interaction between ith square and lth treatment, $\mathrm{e} 1_{\mathrm{ijkl}}=$ whole plot error, $\mathrm{W}_{\mathrm{m}}=$ fixed effect of week ( $\mathrm{m}=1$ to 4$)$ analyzed as repeated measure, $\mathrm{T}_{1}$ $\times \mathrm{W}_{\mathrm{m}}=$ interaction between lth treatment and mth week, $\beta=$ regression coefficient of the covariate term $\operatorname{Cov}_{\mathrm{ijk} k \mathrm{~m}}, \mathrm{Cov}_{\mathrm{ijk} k \mathrm{~m}}=$ covariate variable for the jth cow within the ith square of the lth treatment in the mth week of the kth period, and $\mathrm{e} 2_{\mathrm{ijk} k m}=$ subplot error. The SAS command REPEATED was used to model distinct residual variances. The covariance structures (compound symmetry, autoregressive, and heterogeneous first-order autoregressive) were tested and the one with the smallest Akaike's information criterion coefficient was retained in the final model. The covariate term was removed from the statistical model when $P>0.25$. Significance was declared at $P \leq 0.05$ and trends at $0.05<P \leq 0.10$.

\section{RESULTS}

The nutritional composition of the dietary ingredients is presented in Table 1 . Table 2 shows the AA profile (\% of CP) of different feeds used in the basal diet. The ingredient and nutritional composition of the basal diet are presented in Table 3, and the NRC (2001) evaluation of the experimental diets is shown in Table 4 .

\section{Plasma AA and His-Containing Metabolites}

Treatment effects on plasma concentrations of AA and His-containing metabolites from wk 1 to 3 of each experimental period are shown in Supplemental Tables S1 to S3 (https://doi.org/10.3168/jds.2018-15780), and Table 5 shows plasma AA values during wk 4 . The plasma concentrations of His increased linearly in all 4 wk with feeding incremental amounts of RP-His. Plasma His also showed a quadratic effect in wk 1 (Supplemental Table S1; https://doi.org/10.3168/jds $.2018-15780)$ and a quadratic trend $(P=0.08)$ in wk 3 (Supplemental Table S3; https://doi.org/10.3168/jds .2018-15780). Except for His, treatments did not affect the plasma concentration of the remaining EAA during wk 4 (Table 5); however, RP-His supplementation modified the plasma concentrations of other EAA during wk 1 and 3. For instance, the plasma concentrations of Lys, Met, Phe, Thr, and Trp all responded quadratically to supplemental RP-His during wk $1(P \leq$ $0.05)$. Although no changes were observed in wk 2 , the plasma concentrations of Arg, Leu, Ile Lys, Phe, and Val decreased linearly $(P \leq 0.06)$ in dairy cows fed various levels of RP-His during wk 3. Treatments did not change the plasma concentration of 3-methylhistidine (3-MHis) apart from a quadratic effect $(P=0.03)$ in wk 3. Incremental amounts of RP-His increased the plasma concentration of carnosine linearly in all but wk 2.

\section{Muscle AA Profile and His-Containing Dipeptides}

The effects of various dietary levels of RP-His on concentrations of muscle AA, carnosine, and anserine during wk 2 and 4 of each experimental period are presented in Supplemental Table S4 (https://doi.org/10.3168/jds .2018-15780) and Table 6, respectively. The concentrations of muscle His increased linearly in wk 2 and 4 in response to incremental amounts of RP-His. Whereas muscle Lys concentration increased linearly during wk 2 , no change was observed in wk 4. Muscle Met concentrations were not altered by RP-His throughout the study. The muscle concentrations of other EAA and all NEAA were not affected by treatments during wk 2 

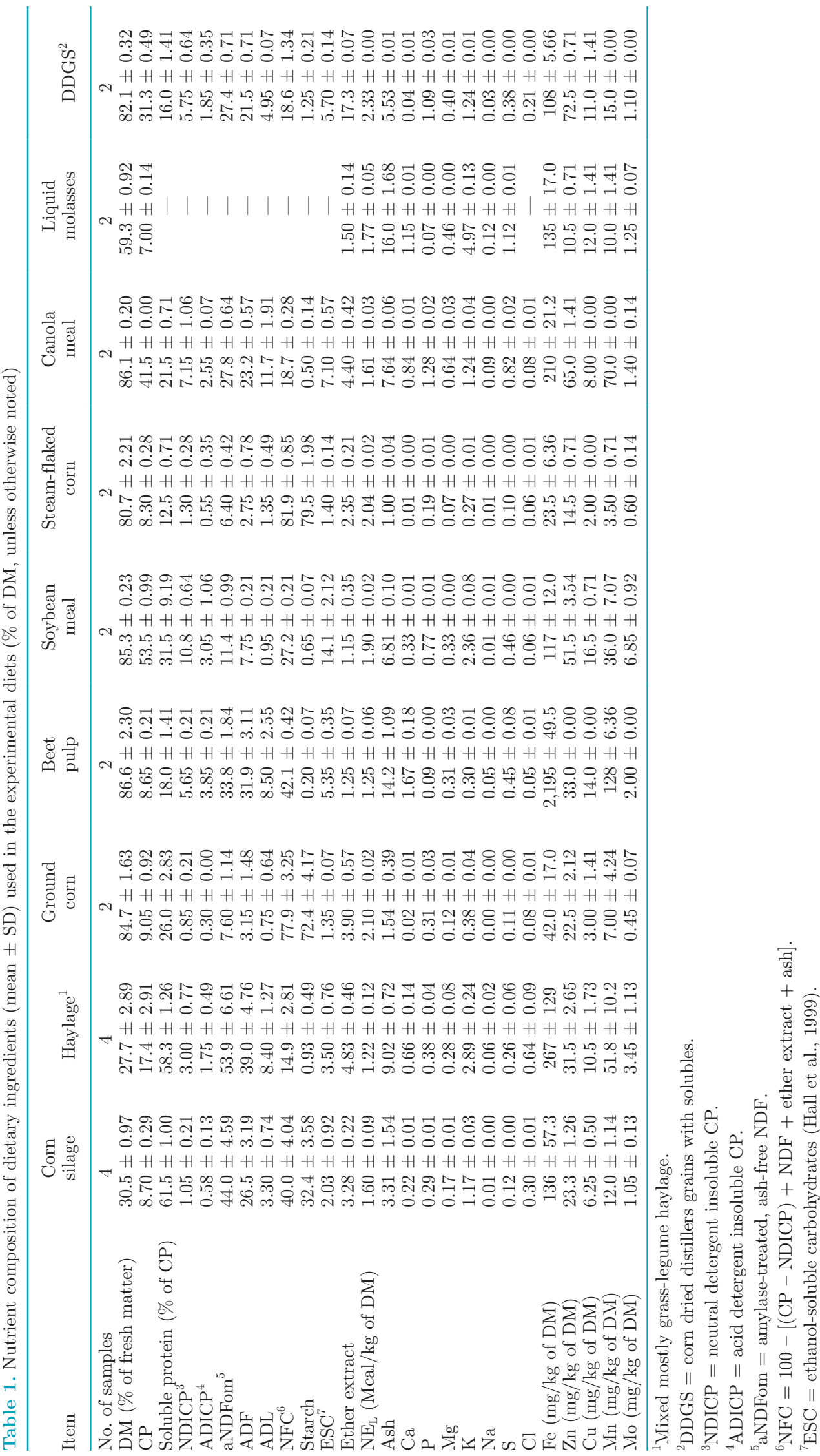
or 4. Likewise, no treatment effects were observed for muscle carnosine and anserine concentrations during wk 4. However, the concentration of muscle carnosine tended $(P=0.08)$ to respond quadratically and that of muscle anserine changed quadratically during wk 2 , with the lowest values observed in cows offered 82 to $164 \mathrm{~g} / \mathrm{d}$ of RP-His.

\section{Nutrient Digestibility and Urinary N Excretion}

Apparent total-tract digestibility of nutrients and urinary excretion of nitrogenous metabolites during wk 4 of each experimental period are shown in Table 7. Treatments did not affect the apparent total-tract digestibilities of DM (mean $=75.3 \%)$, OM $($ mean $=$ $76.8 \%), \mathrm{NDF}($ mean $=65.6 \%), \mathrm{ADF}($ mean $=68.4 \%)$, and $\mathrm{CP}$ (mean $=75.5 \%)$. The urinary concentration of creatinine tended $(P=0.09)$ to decrease linearly with feeding incremental amounts of RP-His. Estimated urinary volume, and urinary excretion of urea- $\mathrm{N}(\mathrm{g} / \mathrm{d}$ and $\%$ of $\mathrm{N}$ intake) and total- $\mathrm{N}(\mathrm{g} / \mathrm{d})$ increased linearly in response to RP-His. In contrast, supplemental RP-His did not affect the output of urea-N expressed as a proportion of total urinary- $\mathrm{N}$ excretion $($ mean $=68.4 \%$ ) or total urinary- $\mathrm{N}$ excretion as a proportion of $\mathrm{N}$ intake $($ mean $=36.8 \%)$. Likewise, urinary excretion of uric acid $($ mean $=39.1 \mathrm{mmol} / \mathrm{d})$, allantoin $($ mean $=464$ $\mathrm{mmol} / \mathrm{d}$ ), and purine derivatives $($ mean $=503 \mathrm{mmol} / \mathrm{d}$ ) was not affected by treatments.

\section{Intake and Milk Yield and Composition}

Dry matter intake, milk yield, concentrations and yields of milk components, PUN, BW, and BCS from wk 1 to 3 of each experimental period are presented in Supplemental Tables S5 to S7 (https://doi.org/10 $.3168 /$ jds.2018-15780), and Table 8 shows production data during wk 4 . Although treatments had no effect on DMI $($ mean $=22 \mathrm{~kg} / \mathrm{d})$, milk yield tended $(P=0.09)$ to increase linearly in cows fed incremental amounts of RP-His (Table 8). Yields of $4 \%$ FCM responded to RP-His in a cubic fashion, whereas ECM tended ( $P$ $=0.06)$ to respond cubically. Feed efficiency expressed as milk yield/DMI and 4\% FCM yield/DMI increased linearly, and ECM yield/DMI showed a cubic response to elevated RP-His. Concentrations of milk fat, true protein, and lactose did not differ and averaged 3.99, 2.99 , and $4.86 \%$ across treatments, respectively. Yield of milk true protein increased linearly and tended $(P=$ $0.07)$ to increase quadratically in cows fed incremental amounts of RP-His. Similarly, milk lactose yield tended $(P=0.06)$ to increase linearly with feeding various levels of RP-His. Concentrations of both MUN (from 11.5 to $13.2 \mathrm{mg} / \mathrm{dL}$ ) and PUN (from 10.7 to $13.0 \mathrm{mg} /$

Table 2. Amino acid composition of dietary ingredients used in the experimental diets ( $\mathrm{n}=1$ composited sample/feedstuff)

\begin{tabular}{|c|c|c|c|c|c|c|c|c|c|}
\hline Item & $\begin{array}{l}\text { Corn } \\
\text { silage }\end{array}$ & Haylage $^{1}$ & $\begin{array}{l}\text { Ground } \\
\text { corn }\end{array}$ & $\begin{array}{l}\text { Beet } \\
\text { pulp }\end{array}$ & $\begin{array}{l}\text { Soybean } \\
\text { meal }\end{array}$ & $\begin{array}{c}\text { Steam-flaked } \\
\text { corn }\end{array}$ & $\begin{array}{c}\text { Canola } \\
\text { meal }\end{array}$ & $\begin{array}{l}\text { Liquid } \\
\text { molasses }\end{array}$ & $\mathrm{DDGS}^{2}$ \\
\hline \multicolumn{10}{|c|}{$\mathrm{EAA}(\%$ of $\mathrm{CP})$} \\
\hline Arg & 2.18 & 3.04 & 4.95 & 1.82 & 7.39 & 4.31 & 6.45 & 0.38 & 4.83 \\
\hline His & 1.51 & 1.77 & 2.92 & 3.07 & 2.66 & 2.96 & 2.94 & 0.38 & 2.82 \\
\hline Ile & 4.53 & 5.49 & 3.81 & 5.03 & 4.92 & 3.90 & 4.57 & 2.29 & 4.56 \\
\hline Leu & 11.6 & 9.20 & 11.3 & 7.40 & 7.90 & 12.1 & 7.68 & 2.29 & 13.0 \\
\hline Lys & 3.02 & 5.40 & 3.81 & 2.65 & 6.57 & 3.36 & 6.22 & 0.76 & 3.28 \\
\hline Met & 2.01 & 1.86 & 2.03 & 2.51 & 1.44 & 2.15 & 2.19 & 0.00 & 2.09 \\
\hline Phe & 4.70 & 5.65 & 4.95 & 4.75 & 5.32 & 5.11 & 4.43 & 1.53 & 5.56 \\
\hline Thr & 3.52 & 4.73 & 3.68 & 5.31 & 3.97 & 3.63 & 4.65 & 2.29 & 4.10 \\
\hline $\operatorname{Trp}$ & 0.67 & 1.18 & 0.89 & 2.51 & 1.52 & 1.08 & 1.46 & $<0.76$ & 0.97 \\
\hline Val & 6.04 & 7.00 & 5.08 & 7.12 & 5.03 & 4.98 & 5.72 & 4.20 & 5.53 \\
\hline \multicolumn{10}{|c|}{ NEAA ( $\%$ of CP) } \\
\hline Ala & 13.3 & 9.54 & 7.23 & 5.03 & 4.39 & 7.40 & 4.77 & 8.78 & 7.26 \\
\hline Asp & 5.70 & 8.95 & 7.49 & 10.6 & 11.5 & 7.13 & 7.77 & 48.9 & 6.65 \\
\hline Cys & 1.68 & 1.10 & 2.41 & 2.09 & 1.56 & 2.42 & 2.83 & 0.76 & 2.28 \\
\hline Gly & 5.03 & 5.74 & 4.31 & 4.89 & 4.37 & 4.04 & 5.49 & 2.29 & 3.67 \\
\hline Glu & 12.3 & 9.28 & 17.5 & 9.36 & 18.0 & 18.2 & 17.8 & 10.3 & 13.9 \\
\hline Orn & 0.67 & 1.27 & 0.13 & 0.28 & 0.08 & 0.13 & 0.08 & 0.00 & 0.12 \\
\hline Pro & 7.38 & 5.65 & 7.87 & 4.47 & 4.73 & 8.21 & 6.14 & 1.53 & 8.31 \\
\hline Ser & 3.02 & 3.38 & 4.44 & 4.47 & 4.35 & 4.58 & 3.90 & 3.05 & 4.68 \\
\hline Tyr & 2.35 & 3.12 & 2.66 & 6.28 & 3.78 & 2.29 & 3.14 & 2.29 & 4.37 \\
\hline Tau & 2.01 & 0.93 & 2.03 & 3.63 & 0.23 & 1.62 & 0.25 & 4.20 & 0.23 \\
\hline
\end{tabular}

${ }^{1}$ Mixed mostly grass-legume haylage.

${ }^{2}$ Corn dried distillers grains with solubles. 
Table 3. Ingredient and nutrient composition (\% of DM, unless otherwise noted) of the basal diet used in the experimental treatments

\begin{tabular}{lc}
\hline Item & Diet \\
\hline Ingredient (\% of DM) & \\
Corn silage & 50.0 \\
Mixed mostly grass-legume haylage & 15.2 \\
Ground corn & 9.17 \\
Beet pulp & 6.79 \\
Soybean meal, 48\% CP & 5.54 \\
Steam-flaked corn & 3.04 \\
BergaFat F100 ${ }^{1}$ & 3.00 \\
Minerals and vitamins premix ${ }^{2}$ & 3.00 \\
Canola meal & 1.75 \\
Liquid molasses & 1.00 \\
Urea & 0.83 \\
Corn dried distillers grains with solubles & 0.58 \\
Smartamine M & 0.05 \\
Nutrient composition & \\
DM (\% of fresh matter) & 41.6 \\
CP & 15.1 \\
aNDFom & 34.8 \\
Forage NDF & 30.2 \\
ADF & 22.7 \\
NFC & 41.4 \\
Ether extract & 6.10 \\
NE & (Mcal/kg of DM) \\
Ca & 1.62 \\
P & 0.80 \\
I & 0.40 \\
\hline
\end{tabular}

${ }^{1}$ BergaFat F100 is a product containing palmitic acid (Berg+Schimidt GmbH \& Co., Hamburg, Germany).

${ }^{2}$ Contained (as-fed basis) $297 \mathrm{mg} / \mathrm{kg}$ of monensin sodium (Rumensin, Elanco, Greenfield, IN), $11.3 \% \mathrm{Ca}, 1.76 \% \mathrm{P}, 5.98 \% \mathrm{Mg}, 6 \% \mathrm{~K}, 3 \% \mathrm{~S}$, $15 \mathrm{mg} / \mathrm{kg}$ of Co, $650 \mathrm{mg} / \mathrm{kg}$ of Cu, $50 \mathrm{mg} / \mathrm{kg}$ of I, $1,200 \mathrm{mg} / \mathrm{kg}$ of Mn, $8.97 \mathrm{mg} / \mathrm{kg}$ of Se, $3,700 \mathrm{mg} / \mathrm{kg}$ of $\mathrm{Zn}$, and $87.1 \mathrm{kIU} / \mathrm{kg}$ of vitamin A.

${ }^{3}$ Urea consists of $95.2 \% \mathrm{DM}$ and $283 \% \mathrm{CP}$.

${ }^{4}$ Smartamine $\mathrm{M}$ is a rumen-protected Met supplement (Adisseo USA Inc., Alpharetta, GA).

${ }^{5}$ aNDFom $=$ amylase-treated, ash-free NDF

$\mathrm{dL})$ increased linearly. There were no treatment effects for BCS $($ mean $=3.10)$, BW $($ mean $=728 \mathrm{~kg})$, and BW change $($ mean $=0.17 \mathrm{~kg} / \mathrm{d})$ in the current experiment.

\section{Temporal Changes of Plasma and Muscle His and His-Containing Metabolites}

No week or treatment by week interaction effect was observed for the plasma concentration of His in cows fed incremental amounts of RP-His (Figure 1A). Plasma carnosine concentration did not differ between wk 1 and 2 and increased thereafter $(P<0.001$; Figure $1 \mathrm{~B})$; however, no treatment $\times$ week interaction was detected. Although no treatment by week interaction was observed for 3-MHis, its plasma concentration was greatest in wk 2 , intermediate in wk 1 , and lowest in wk 3 and 4 (Figure $1 \mathrm{C} ; P<0.01$ ). No week or treatment $\times$ week interaction was observed for muscle His in response to RP-His supplementation (Figure 2A). We did not observe any effect of week or treatment $x$ week interaction for muscle concentration of carnosine or anserine (Figures $2 \mathrm{~B}$ and $2 \mathrm{C}$, respectively).

\section{DISCUSSION}

The proportions of His, Met, and Lys of corn silage, mixed mostly grass-legume haylage, and ground corn differed slightly from those reported in the NRC (2001), and larger differences in AA profile were observed for the remaining feedstuffs. The basal diet averaged 15.1\% $\mathrm{CP}$ and has adequate NFC concentration (mean = $41.4 \%$ ). The forage NDF concentration averaged 30\% due to the high dietary forage-to-concentrate ratio (65:35) of our basal diet.

According to the NRC (2001), dietary $\mathrm{NE}_{\mathrm{L}}$ supplies were above the requirements for all experimental diets and the $\mathrm{NE}_{\mathrm{L}}$ balance ranged from $0.4 \mathrm{Mcal} / \mathrm{d}$ in cows fed $246 \mathrm{~g} / \mathrm{d}$ of RP-His to $2.4 \mathrm{Mcal} / \mathrm{d}$ in those that did not receive RP-His. The supplies of $\mathrm{MP}$ varied from 1 to $6 \%$ below the requirements, with the greatest MP deficiency (i.e., $-136 \mathrm{~g} / \mathrm{d}$ ) observed in cows fed 246 $\mathrm{g} / \mathrm{d}$ of RP-His. All 4 diets provided adequate RDP ( $\sim 3 \%$ above the requirements), whereas dietary RUP balance varied from 4 to $15 \%$ below the requirements and displayed a pattern like that observed for MP balance. An $8 \%$ deficiency in dHis relative to requirement was estimated for the control diet (i.e., $0 \mathrm{~g} / \mathrm{d}$ of RP-His). However, surpluses of 13\% (164 g/d of RPHis) and $18 \%$ (246 g/d of RP-His) or no deficiency $(82 \mathrm{~g} / \mathrm{d}$ of RP-His) were also observed. Although dMet supplies exceeded the requirements across all 4 diets, dMet balance slightly decreased from +8 to $+6 \mathrm{~g} / \mathrm{d}$ as supplemental RP-His increased from 0 to $246 \mathrm{~g} / \mathrm{d}$. The requirements (from 143 to $148 \mathrm{~g} / \mathrm{d}$ ) and supplies (from 144 to $141 \mathrm{~g} / \mathrm{d}$ ) of dLys changed with feeding incremental amounts of RP-His, resulting in a dLys balance that went from slightly positive $(+1 \mathrm{~g} / \mathrm{d} ; 0 \mathrm{~g} / \mathrm{d} \mathrm{RP}$-His diet $)$ to negative $(-7 \mathrm{~g} / \mathrm{d} ; 246 \mathrm{~g} / \mathrm{d} \mathrm{RP}$-His diet). This may have happened because a source of RP-Lys was not used in the current study or due to the high inclusion of corn silage (i.e., $50 \%$, DM basis) in the basal diet.

A linear response in plasma His was observed in the first week after the beginning of RP-His supplementation, indicating that short-length periods (i.e., 7-d long) in a Latin square design may be suitable to assess the relative bioavailability of His from RP-His supplements as reported for Lys from RP-Lys products (Whitehouse et al., 2017). A sharp elevation in circulating His was observed between 0 and $164 \mathrm{~g} / \mathrm{d}$ of RP-His supplementation, which was followed by a less pronounced increase from 164 to $246 \mathrm{~g} / \mathrm{d}$ of RP-His. This was expected because dHis balance averaged -4 , $0,+6$, and $+9 \mathrm{~g} / \mathrm{d}$ in cows fed $0,82,164$, and 246 
Table 4. NRC (2001) evaluation of the experimental diets containing incremental amounts of rumen-protected His (RP-His)

\begin{tabular}{|c|c|c|c|c|}
\hline \multirow[b]{2}{*}{ Item $^{2}$} & \multicolumn{4}{|c|}{ RP-His } \\
\hline & $0 \mathrm{~g} / \mathrm{d}$ & $82 \mathrm{~g} / \mathrm{d}$ & $164 \mathrm{~g} / \mathrm{d}$ & $246 \mathrm{~g} / \mathrm{d}$ \\
\hline \multicolumn{5}{|l|}{$\mathrm{NE}_{\mathrm{L}}(\mathrm{Mcal} / \mathrm{d})$} \\
\hline Requirement & 34.0 & 34.4 & 34.2 & 35.3 \\
\hline Supply & 36.4 & 35.8 & 36.3 & 35.7 \\
\hline Balance & 2.4 & 1.4 & 2.1 & 0.4 \\
\hline \multicolumn{5}{|l|}{$\operatorname{MP}(\mathrm{g} / \mathrm{d})$} \\
\hline Requirement & 2,170 & 2,184 & 2,190 & 2,243 \\
\hline Supply & 2,141 & 2,107 & 2,141 & 2,107 \\
\hline Balance & -29 & -77 & -49 & -136 \\
\hline \multicolumn{5}{|l|}{$\operatorname{RDP}(g / d)$} \\
\hline Requirement & 2,256 & 2,218 & 2,247 & 2,210 \\
\hline Supply & 2,327 & 2,284 & 2,316 & 2,276 \\
\hline Balance & 70 & 67 & 69 & 66 \\
\hline \multicolumn{5}{|l|}{ RUP (g/d) } \\
\hline Requirement & 1,068 & 1,115 & 1,101 & 1,198 \\
\hline Supply & 1,030 & 1,014 & 1,024 & 1,017 \\
\hline Balance & -38 & -101 & -77 & -181 \\
\hline \multicolumn{5}{|l|}{$\mathrm{dHis}^{3}(\mathrm{~g} / \mathrm{d})$} \\
\hline Requirement $^{4}$ & 48 & 48 & 48 & 49 \\
\hline Supply from the diet & 44 & 43 & 44 & 43 \\
\hline Supply from RP-His & 0 & 5 & 10 & 15 \\
\hline Balance & -4 & 0 & 6 & 9 \\
\hline \multicolumn{5}{|l|}{$\mathrm{dMet}^{3}(\mathrm{~g} / \mathrm{d})$} \\
\hline Requirement ${ }^{4}$ & 48 & 48 & 48 & 49 \\
\hline Supply from the diet & 49 & 49 & 49 & 48 \\
\hline Supply from RP-Met ${ }^{5}$ & 7 & 7 & 7 & 7 \\
\hline & 8 & 8 & 7 & 6 \\
\hline \multicolumn{5}{|l|}{$\mathrm{dLys}^{3}(\mathrm{~g} / \mathrm{d})$} \\
\hline Requirement ${ }^{4}$ & 143 & 144 & 145 & 148 \\
\hline Supply & 144 & 141 & 143 & 141 \\
\hline Balance & 1 & -3 & -2 & -7 \\
\hline
\end{tabular}

${ }^{1} \mathrm{RP}$-His is a prototype supplement (Ajinomoto Co. Inc., Kawasaki-shi, Japan).

${ }^{2}$ All values were estimated using the NRC (2001) based on actual DMI, DIM, milk yield and composition, and BW of the cows.

${ }^{3} \mathrm{dHis}$, dMet, and dLys represent digestible His, Met, and Lys, respectively.

${ }^{4}$ Requiements of dHis, dMet, and dLys were calculated as 2.2, 2.2, and $6.6 \%$ of MP requirements, respectively.

${ }^{5} \mathrm{RP}-$ Met is Smartamine M (Adisseo USA Inc., Alpharetta, GA).

$\mathrm{g} / \mathrm{d}$ of RP-His, respectively. The increase in plasma His with feeding $246 \mathrm{~g} / \mathrm{d}$ of RP-His ( $15 \mathrm{~g} / \mathrm{d}$ of dHis) ranged from $87 \%$ (wk 2) to $99 \%$ (wk 3) relative to the control diet. Lapierre et al. (2014) and Ouellet et al. (2014) reported that the plasma concentration of His increased by 258 and $157 \%$, respectively, after abomasal infusion of $15.2 \mathrm{~g} / \mathrm{d}$ of His in lactating dairy cows. The lower response in plasma His to supplemental His compared with Lapierre et al. (2014) and Ouellet et al. (2014) is consistent with dietary His supply being less deficient herein $(2.06 \%$ of MP supply) than in these 2 earlier studies (mean $=1.55 \%$ of MP supply), suggesting that excess His was catabolized in the liver with the carbon skeleton used for energy supply and the amino group for urea synthesis. In fact, concentrations of MUN and PUN increased linearly in cows fed various levels of RP-His, which was consistent with both deamination of His and enhanced N intake. Supplementation of RPHis has been shown to increase plasma concentration of His in most (Lee et al., 2012; Giallongo et al., 2016, 2017) but not all studies (Giallongo et al., 2015), likely due to differences in MP balance across experiments. In addition, the methodology used to determine the bioavailability of His from RP-His supplements can result in varied estimations of dHis ultimately affecting the concentration of His in plasma.

Apart from His, incremental amounts of RP-His had no effects on plasma EAA concentrations during wk 4 but changes were observed during wk 1 to 3 . These inconsistencies in weekly plasma EAA concentrations are possibly associated with the time required for cows to adapt to a new diet, variation in the AA profile of feeds, stage of lactation, and level of DMI and milk yield. In addition, a quadratic response in the plasma concentration of 3 -MHis during wk 3 without changes in wk 1 , 2 , or 4 suggests transient muscle protein proteolysis. According to Houweling et al. (2012), the catabolism of actin and myosin in skeletal muscles releases 3-MHis, 
Table 5. Plasma concentrations of AA and His-containing metabolites in mid-lactation dairy cows fed incremental amounts of rumen-protected His (RP-His) $)^{1}$ during wk 4 of each experimental period ${ }^{2}$

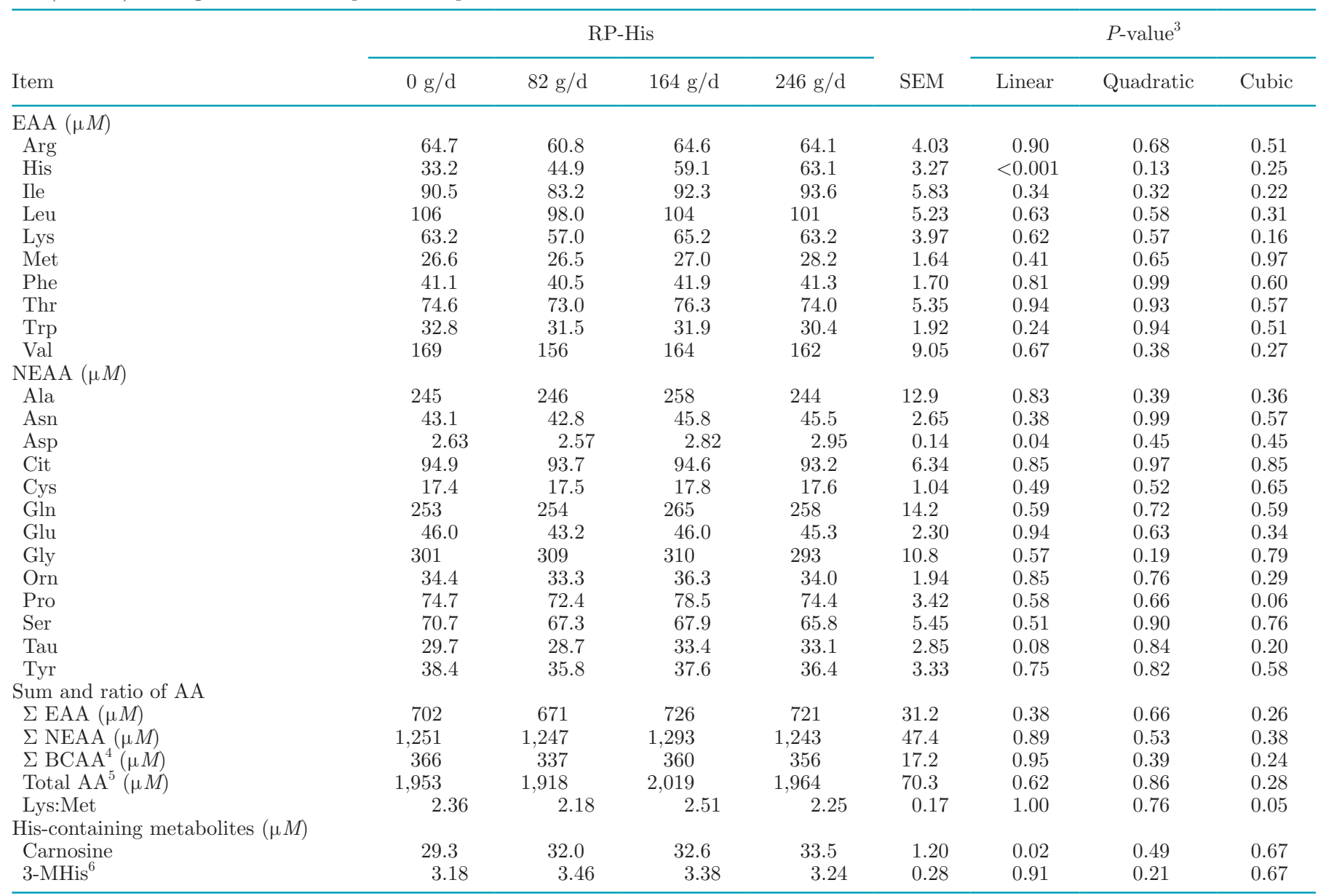

${ }^{1}$ The RP-His used is a prototype supplement (Ajinomoto Co. Inc., Kawasaki-shi, Japan).

${ }^{2} \mathrm{Wk} 4=\mathrm{d} 22$ to 28 of periods 1 to 4 .

${ }^{3}$ Orthogonal polynomials were used to test linear, quadratic, and cubic effects; significance was declared at $P \leq 0.05$ and trends at $0.05<P \leq$ 0.10

${ }^{4} \mathrm{BCAA}=$ branched-chain $\mathrm{AA}$

${ }^{5}$ Total $\mathrm{AA}=\mathrm{EAA}+\mathrm{NEAA}$.

${ }^{6} 3$-MHis $=3$-methylhistidine.

which has been considered a reliable indicator of muscle proteolysis in cattle (Harris and Milne, 1981). Swick and Benevenga (1977) concluded that the breakdown of muscle protein to provide AA for milk protein synthesis is a mechanism of normal metabolic adaptation sensitive to dietary changes. Alternatively, it cannot be disregarded that some of these inconsistencies seen in our weekly plasma EAA data set may be random and an artifact of large number of AA analyses.

Comparable to our results, Ouellet et al. (2014) reported a linear increase in the plasma concentration of carnosine in cows abomasally infused with incremental amounts of His (0 to $38 \mathrm{~g} / \mathrm{d}$ ). More than $99 \%$ of carnosine, which is synthesized by carnosine synthase using His and Ala, is found in skeletal muscles (Maynard et al.,
2001; Boldyrev et al., 2013). Therefore, it is conceivable that increased circulating concentrations of carnosine observed herein may be related to its transportation from skeletal muscles to plasma. Everaert et al. (2013) demonstrated that mRNA transcripts of the peptide/ His transporter 1 and 2 were found in skeletal muscle samples of mouse and humans even though no data appear to be available for ruminants. Transportation from muscle to plasma may be related to the metabolic functions of carnosine including $\mathrm{pH}$ buffering, metal-ion chelation, antioxidant activity, and protection against the formation of advanced glycation and lipoxidation end products (Boldyrev et al., 2013). However, Lee et al. (2012) and Giallongo et al. (2015) reported no effect of $50 \mathrm{~g} / \mathrm{d}$ of RP-His supplementation (54\% estimated 
Table 6. Muscle concentrations of AA and His-containing dipeptides in mid-lactation dairy cows fed incremental amounts of rumen-protected His $(\mathrm{RP}-\mathrm{His})^{1}$ during wk 4 of each experimental period ${ }^{2}$

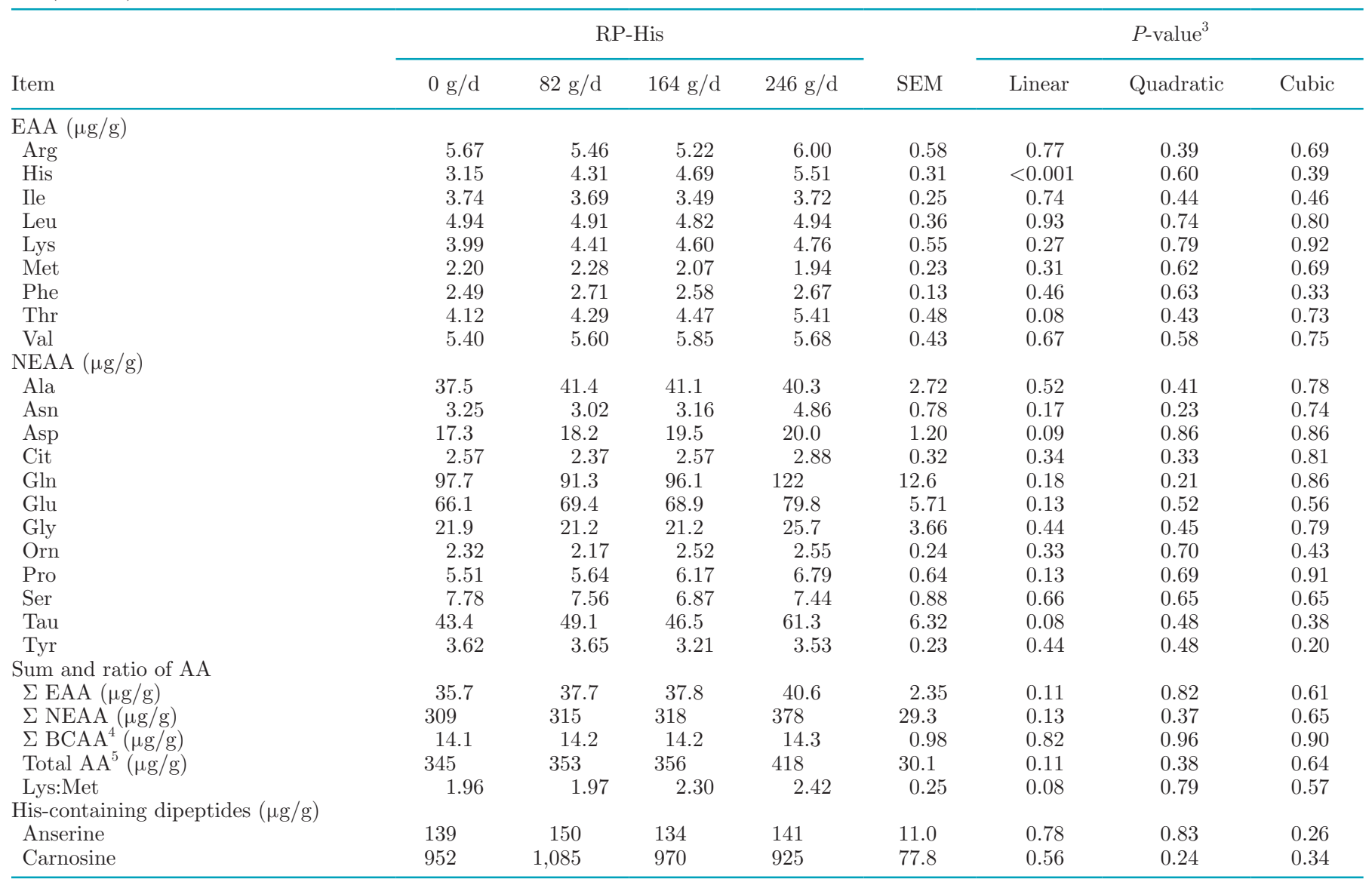

${ }^{1}$ The RP-His used is a prototype supplement (Ajinomoto Co. Inc., Kawasaki-shi, Japan).

${ }^{2} \mathrm{Wk} 4=\mathrm{d} 22$ to 28 of periods 1 to 4 .

${ }^{3}$ Orthogonal polynomials were used to test linear, quadratic, and cubic effects; significance was declared at $P \leq 0.05$ and trends at $0.05<P \leq$ 0.10 .

${ }^{4} \mathrm{BCAA}=$ branched-chain $\mathrm{AA}$.

${ }^{5}$ Total $\mathrm{AA}=\mathrm{EAA}+\mathrm{NEAA}$.

bioavailability) on plasma carnosine concentration of dairy cows, which was thus in disagreement with the results from the current study. Differences in the extent of MP deficiency, amount of RP-His fed, bioavailability estimations, and experimental design (changeover vs. continuous) may have all played a role in these discrepant results.

The muscle concentrations of His increased linearly during wk 2 and 4 in cows fed different levels of supplemental RP-His, thus consistent with increased plasma His concentration. In contrast, Giallongo et al. (2015) reported no change in muscle His concentration in dairy cows offered a MP-deficient diet supplemented with 50 $\mathrm{g} / \mathrm{d}$ of RP-His, possibly because less RP-His was fed in their study than in the current experiment (82 to $246 \mathrm{~g} / \mathrm{d}$ ). Muscle Lys and Met concentrations were not altered by RP-His supplementation, except a linear increase in Lys during wk 2. Giallongo et al. (2015) reported no differences in the muscle concentrations of Lys and Met in lactating dairy cows fed RP-His. Discrepancies in muscle His concentrations between the present study and Giallongo et al. (2015) are potentially explained by animal, dietary, and experimental design factors discussed above.

Muscle carnosine and anserine concentrations were not affected by treatments during wk 4; however, a quadratic effect for anserine and a trend for carnosine were detected in wk 2 , with the lowest values observed in cows offered 82 and $164 \mathrm{~g} / \mathrm{d}$ of RP-His. Lapierre et al. (2014) reported linear and quadratic trends for the muscle concentration of anserine, and a quadratic trend for that of carnosine in lactating dairy cows abomasally infused with increasing amounts of His $(0$, $7.6,15.2$, and $22.8 \mathrm{~g} / \mathrm{d}$ ) in a Latin square study with 
Table 7. Apparent total-tract digestibility of nutrients and urinary excretion of nitrogenous compounds in mid-lactation dairy cows fed incremental amounts of rumen-protected His (RP-His) ${ }^{1}$ during wk 4 of each experimental period ${ }^{2}$

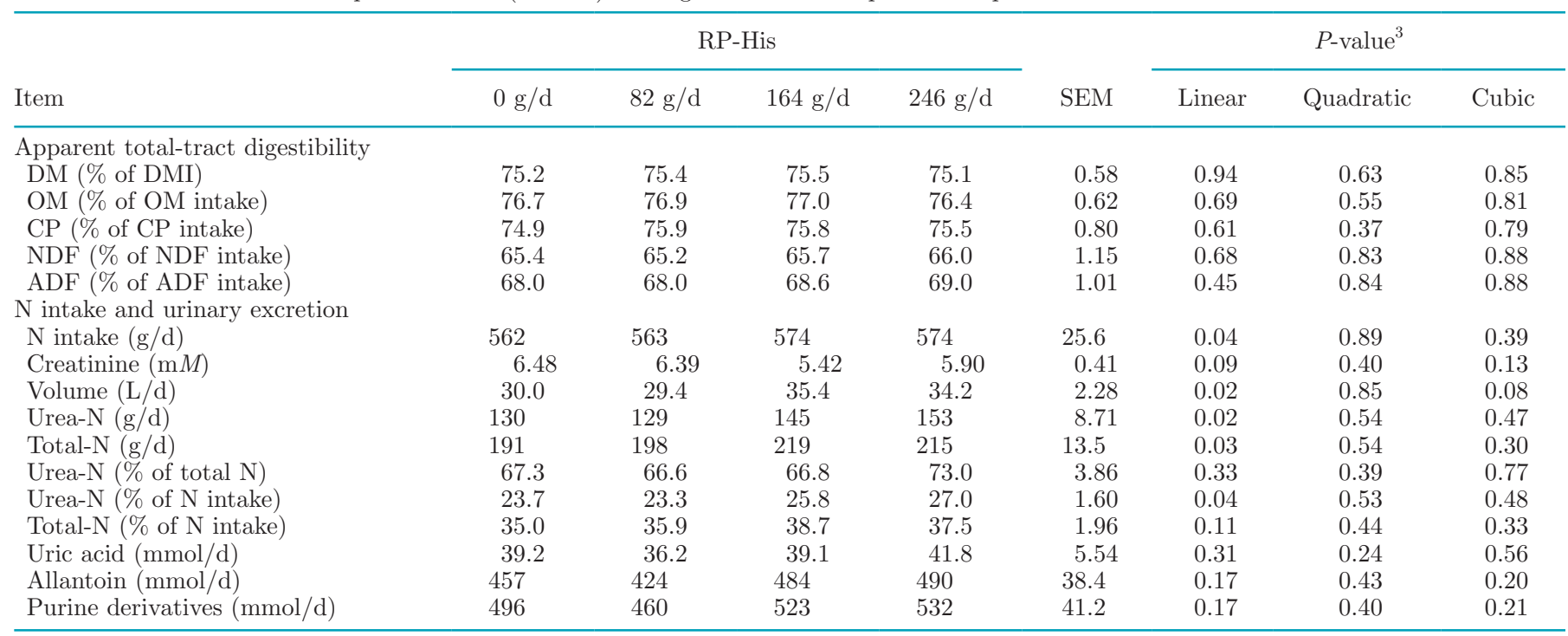

${ }^{1}$ The RP-His used is a prototype supplement (Ajinomoto Co. Inc., Kawasaki-shi, Japan).

${ }^{2} \mathrm{Wk} 4=\mathrm{d} 22$ to 28 of periods 1 to 4 .

${ }^{3}$ Orthogonal polynomials were used to test linear, quadratic, and cubic effects; significance was declared at $P \leq 0.05$ and trends at $0.05<P \leq$ 0.10 .

14-d periods. It has been proposed that intramuscular carnosine and anserine, and blood hemoglobin could serve as endogenous sources of His during short-term deficiency (Lapierre et al., 2008). Hemoglobin was not measured and the muscle concentrations of anserine and carnosine responded quadratically only during wk

Table 8. Dry matter intake, milk yield, concentrations and yields of milk components, feed efficiency, concentration of plasma urea N (PUN), $\mathrm{BW}$, and BCS in mid-lactation dairy cows fed incremental amounts of rumen-protected His (RP-His) ${ }^{1}$ during wk 4 of each experimental period ${ }^{2}$

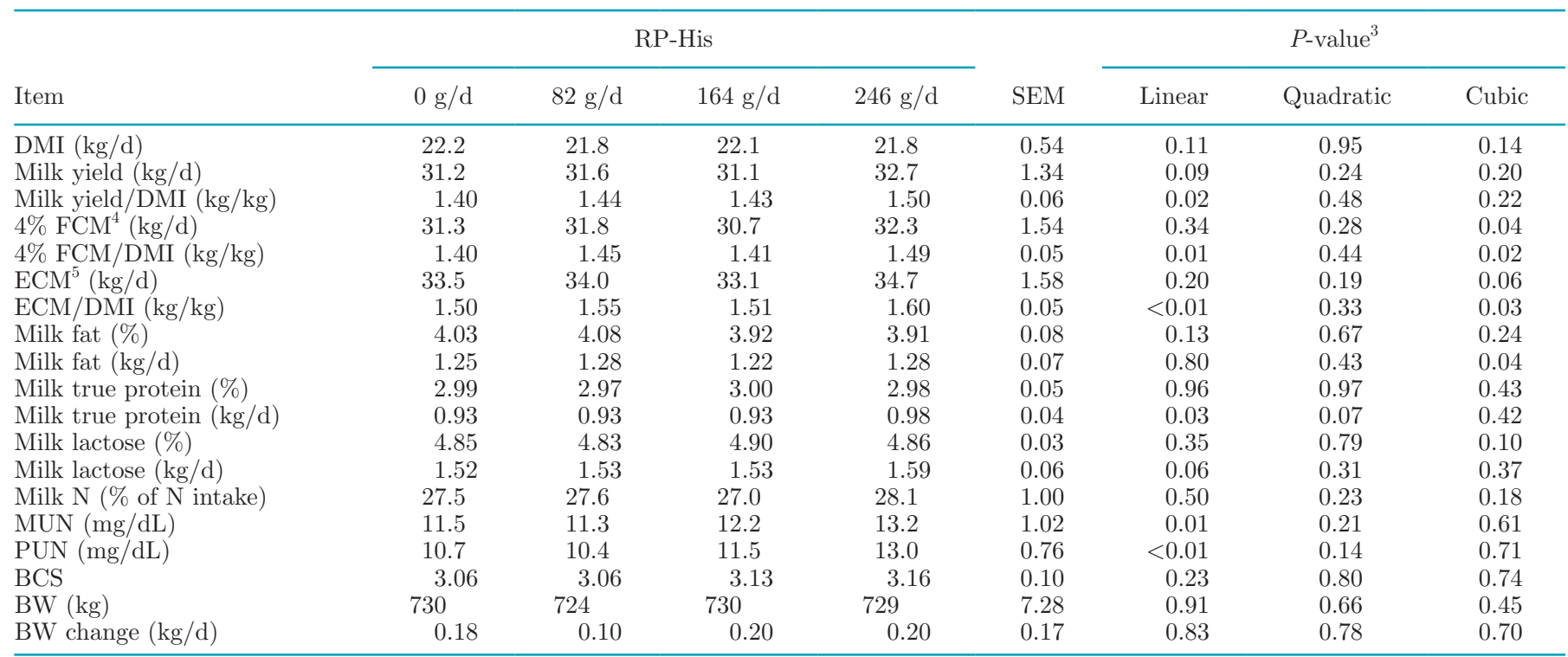

${ }^{1}$ The RP-His used is a prototype supplement (Ajinomoto Co. Inc., Kawasaki-shi, Japan).

${ }^{2} \mathrm{Wk} 4=\mathrm{d} 22$ to 28 of periods 1 to 4 .

${ }^{3}$ Orthogonal polynomials were used to test linear, quadratic, and cubic effects; significance was declared at $P \leq 0.05$ and trends at $0.05<P \leq$ 0.10 .

${ }^{4} 4 \% \mathrm{FCM}=(0.4 \times \mathrm{kg}$ of milk $)+(15 \times \mathrm{kg}$ of milk fat $) ;$ Gaines and Davidson (1923).

${ }^{5} \mathrm{ECM}=(0.327 \times \mathrm{kg}$ of milk $)+(12.95 \times \mathrm{kg}$ of milk fat $)+(7.65 \times \mathrm{kg}$ of milk protein $) ;$ Tyrrell and Reid (1965) 
A
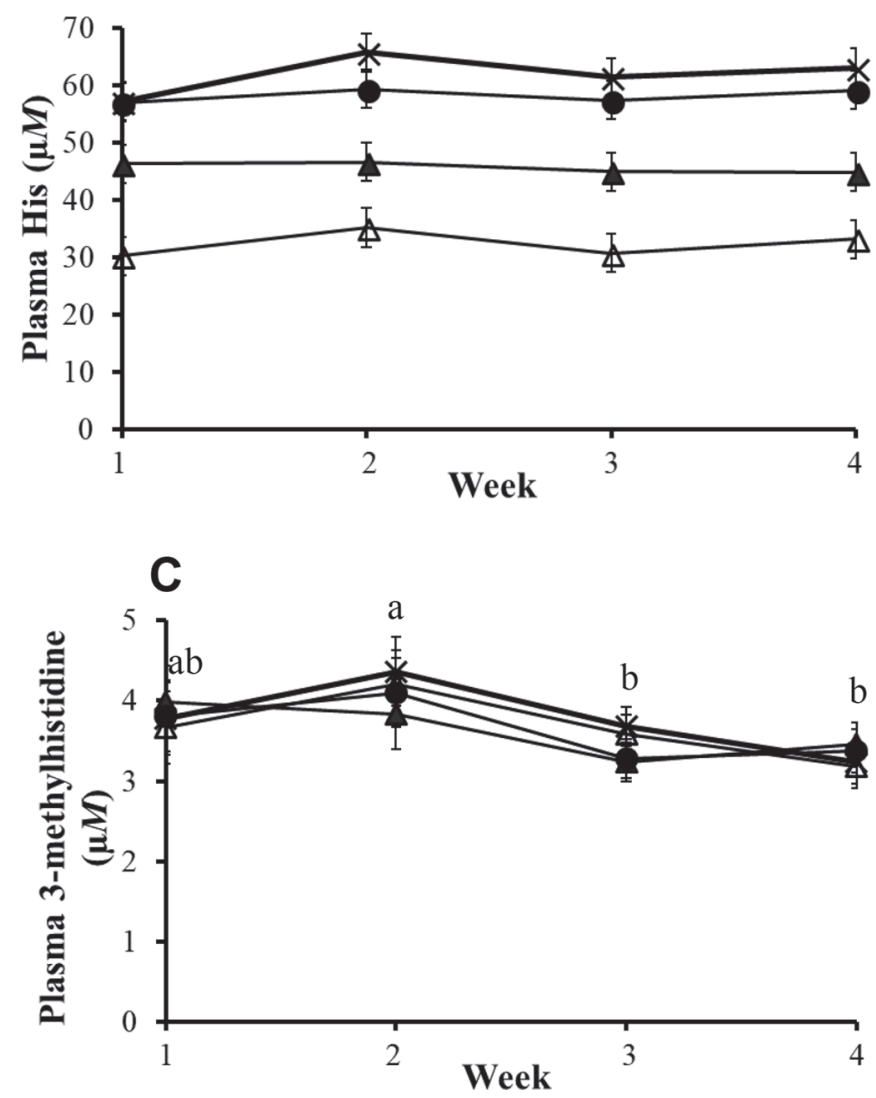

B

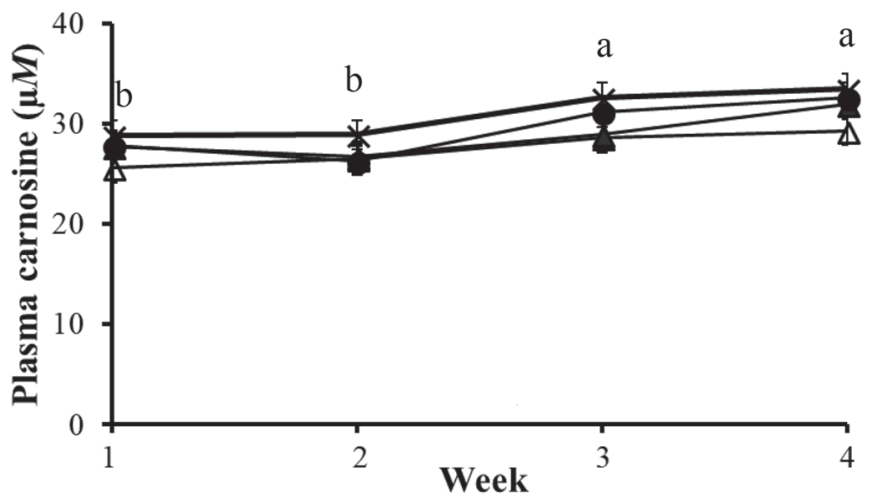

$\triangle 0 \mathrm{~g} / \mathrm{d} \mathrm{RP}$-His

\$ $82 \mathrm{~g} / \mathrm{d}$ RP-His

- $164 \mathrm{~g} / \mathrm{d}$ RP-His

*246 g/d RP-His

Figure 1. Plasma concentrations of $(\mathrm{A})$ His (treatment: $P<0.001$; week: $P=0.13$; treatment $\times$ week: $P=0.93$; SEM $=2.54)$, $(\mathrm{B})$ carnosine (treatment: $P<0.001$; week: $P<0.001$; treatment $\times$ week: $P=0.89$; SEM $=0.73$ ), and $(\mathrm{C}) 3$-methylhistidine $($ treatment: $P=0.93$; week: $P$ $<0.01$; treatment $\times$ week: $P=0.76 ;$ SEM $=0.23)$ in mid-lactation dairy cows fed incremental amounts of rumen-protected His $(\mathrm{RP}-$ His $)$. Wk 1 (d 1 to 7 ), wk 2 (d 8 to 14), wk 3 (d 15 to 21), and wk 4 (d 22 to 28) of periods 1, 2, 3, and 4. Data are presented as LSM \pm SEM. ${ }^{\text {,b Means }}$ with different letters across week differ at $P \leq 0.05$. The RP-His used is a prototype supplement (Ajinomoto Co. Inc., Kawasaki-shi, Japan).

2, indicating that based on the available data no definite conclusions can be made regarding the use of these 2 His-containing dipeptides as endogenous sources of His under the conditions of our study.

A decoupled response between plasma (increased linearly) and muscle (no change) carnosine concentrations during wk 4 was observed in the present study and agrees with data from Giallongo et al. (2017). Davey (1960) and Maynard et al. (2001) reported significant variations in carnosine concentrations among different skeletal muscles within individual animals and among the same type of muscles across different species, indicating that muscle fiber profile may be involved in these responses. For instance, the concentration of carnosine increased 5-fold in the predominant oxidative fiber soleus muscle but not in the predominant glycolytic-oxidative fiber red vastus lateralis muscle or predominant oxidative white vastus lateralis muscle of rats fed carnosine (Maynard et al., 2001). The longissimus dorsi muscle contains more glycolytic than oxidative fibers (Kirchofer et al., 2002), which may explain the lack of effect of RP-His on muscle carnosine concentration. Whereas muscle carnosine concentration increased steadily following oral administration of $\beta$-alanine to humans (Harris et al., 2006), plasma carnosine did not follow the same pattern due to the high activity of serum carnosinase-1 (Jackson et al., 1991; Everaert et al., 2012; Boldyrev et al., 2013). However, serum carnosinase- 1 is not expressed in serum of ruminants (Jackson et al., 1991). Thus, this decoupled muscleplasma carnosine response could be also associated with the lack of serum carnosinase in cattle.

Supplementation of RP-His had no effects on apparent total-tract digestibility of nutrients in the present study. However, the total-tract digestibilities of NDF $($ mean $=65.6 \%)$ and ADF $($ mean $=68.4 \%)$ appear to be overestimated possibly because of uncertainties associated with the adoption of iADF as the internal marker to estimate fecal output of DM. Recently, Velásquez et al. (2018) reported that the fecal recoveries of iADF av- 
eraged $147 \%$ with 2 fecal grab sampling procedures and $153 \%$ with a pooled sample obtained over $3 \mathrm{~d}$ of total collection in Holstein cows fed a corn silage-based diet. Fecal recovery greater than $100 \%$ can underestimate fecal DM output, resulting in overestimation of apparent total-tract fiber digestibility. Alternatively, cows in the present study consumed a moderate amount of DM $($ mean $=22 \mathrm{~kg} / \mathrm{d})$, which may have slowed down the digesta passage rate leading to increased fiber digestibility. Ferraretto and Shaver (2015) reported in their meta-analysis a range in apparent total-tract digestibility of NDF from 24.2 to $62.5 \%$ (mean $=43.8 \%$ ) in dairy cows consuming diets containing corn silage harvested from different types of corn hybrids. We obtained an apparent total-tract NDF digestibility of $42 \%$ using the prediction equation of de Souza et al. (2018) (i.e., NDF digestibility $=53+0.26 \times \%$ of grass silage in diet $\mathrm{DM}-0.59 \times \%$ starch in $\operatorname{diet} \mathrm{DM}+3.06 \times \mathrm{DMI}$ as
$\%$ of $\mathrm{BW}-0.46 \times \mathrm{DMI}$ as $\%$ of $\left.\mathrm{BW}^{2}\right)$. This suggests that NDF digestibility may have been overestimated by 23 percentage units when using iADF as the internal marker. Nevertheless, our sampling protocol resulted in 8 fecal grab samples per cow over a 3 -d period, thus following literature recommendations for improved estimation accuracy of nutrient digestibility in the total gastrointestinal tract (e.g., Sampaio et al., 2011; Morris et al., 2018; Velásquez et al., 2018).

Urinary excretion of urea- $\mathrm{N}(\mathrm{g} / \mathrm{d}$ and $\%$ of $\mathrm{N}$ intake) and total-N (g/d) responded linearly to RP-His supplementation. In contrast, Giallongo et al. (2015) reported no changes in urinary excretion of urea- $\mathrm{N}$ and total$\mathrm{N}$ with feeding $50 \mathrm{~g} / \mathrm{d}$ of RP-His to lactating dairy cows. Greater amounts of supplemental RP-His in the present study compared with that (84 to $246 \mathrm{~g} / \mathrm{d}$ vs. $50 \mathrm{~g} / \mathrm{d}$ ) from Giallongo et al. (2015) led to elevated urinary $\mathrm{N}$ excretion, suggesting that excess His was
A
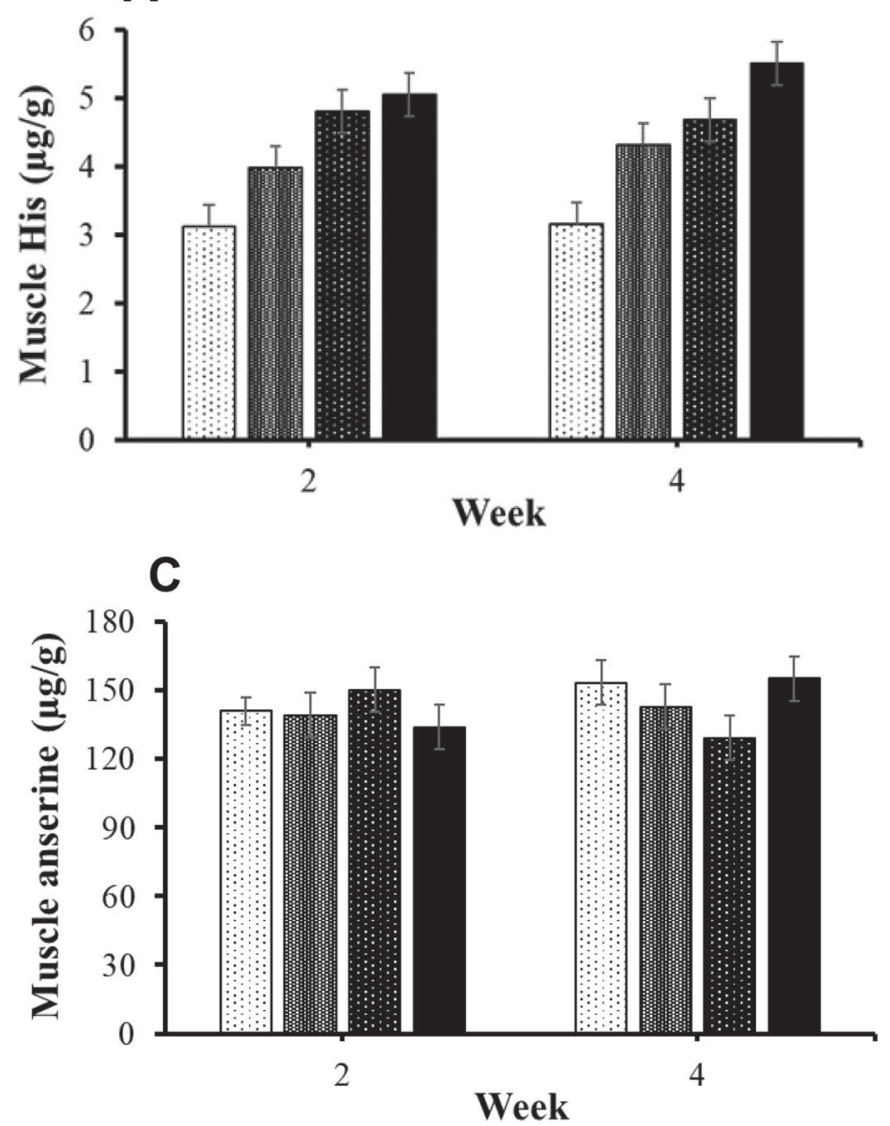

B

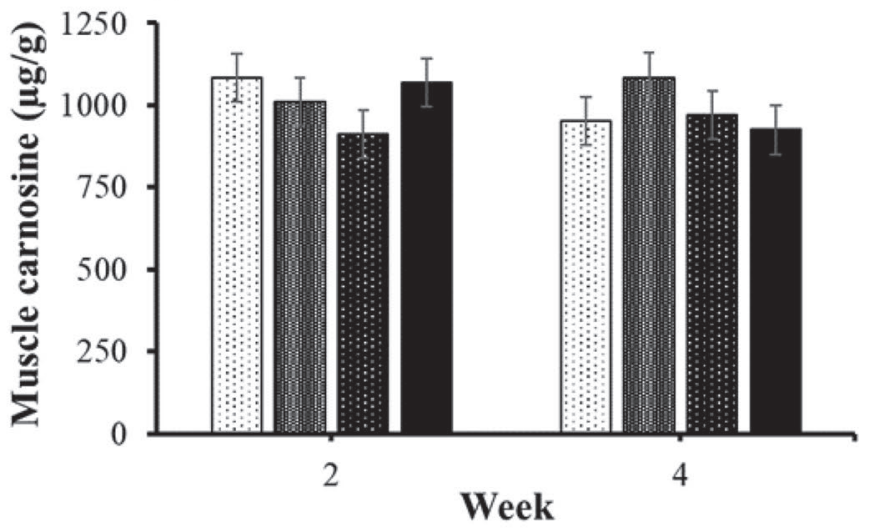

Figure 2. Muscle concentrations of $(\mathrm{A})$ His (treatment: $P<0.001$; week: $P=0.44$; treatment $\times$ week: $P=0.78$; SEM $=0.23)$, $(\mathrm{B})$ carnosine (treatment: $P=0.48$; week: $P=0.46$; treatment $\times$ week: $P=0.23$; SEM $=55.2$ ), and $(\mathrm{C})$ anserine $($ treatment: $P=0.21$; week: $P=0.50$; treatment $\times$ week: $P=0.43 ; \mathrm{SEM}=7.56)$ in mid-lactation dairy cows fed incremental amounts of rumen-protected His $(\mathrm{RP}-\mathrm{His})$. Wk 2 (d 8 to 14) and wk 4 (d 22 to 28) of periods 1, 2, 3, and 4. Data are presented as LSM \pm SEM. The RP-His used is a prototype supplement (Ajinomoto Co. Inc., Kawasaki-shi, Japan). 
deaminated with ammonia being converted to urea in the liver. Alternatively, the bioavailability of His from the RP-His supplement fed in our study may have been underestimated, resulting in excess His supply relative to requirements. Holter et al. (1982) demonstrated that urine volume responded to increased $\mathrm{N}$ intake, which agrees with results from the present study. Lee et al. (2012) and Giallongo et al. (2015) did not observe effects of RP-His on urinary excretion of uric acid, allantoin, and purine derivatives also in concordance with our results.

We observed that supplemental RP-His tended to improve milk yield linearly without an effect on DMI, resulting in improved feed efficiency (i.e., milk yield/ DMI). In comparison, Lapierre et al. (2014) reported that DMI tended to increase linearly and milk yield increased linearly with abomasal infusions of His in dairy cows fed a 28\% MP-deficient diet. Ouellet et al. (2014) observed linear increases in both DMI and milk yield with various amounts of abomasal infusions of His in 25\% MP-deficient diets. Our basal diet was only $1.3 \%$ deficient in MP and may explain to a certain extent the discrepant results between the current and previous studies (Lapierre et al., 2014; Ouellet et al., 2014). Giallongo et al. (2016) fed 2\%-MP-deficient diets supplemented or not with RP-Lys, RP-Met, or RP-His or containing all 3 RP-AA. Specifically, cows fed the MP-deficient diet plus RP-His (not balanced for Lys and Met) showed a tendency for increased DMI and no changes in yields of milk or ECM compared with those offered a MP-deficient ration without RP-AA supplementation (Giallongo et al., 2016). It should be noted that our diets went from slightly adequate to deficient in dLys, which may have affected milk yield responses as Lys together with Met are considered co-limiting AA in typical US dairy diets (Schwab et al., 1976; NRC, 2001). Altogether, these results suggest that in addition to MP balance, the ingredient composition of the basal diet, production level, DIM, amount of supplemental His, and status of dLys, dMet, dHis, and possibly other EAA may be also involved in the discrepant results in DMI and milk yield across the literature in cows fed $\mathrm{RP}-\mathrm{His}$ or receiving postruminal infusions of His.

Yields of 4\% FCM and milk fat responded cubically, whereas ECM yield tended to respond cubically in cows fed incremental amounts of RP-His in the present study. Korhonen et al. (2000) reported cubic responses in concentration and yield of milk fat in dairy cows fed grass silage-based diets infused postruminally with 0 , 2, 4, or $6 \mathrm{~g}$ of His/d. Although these cubic effects are difficult to explain biologically, they may be related to imbalances of nutrient supply at the gut or mammary tissues (Korhonen et al., 2000). In addition, a low num- ber of cows $(n=8)$ was used in our study, indicating that milk yield and milk composition data should be interpreted cautiously.

Milk true protein yield averaged $0.93 \mathrm{~kg} / \mathrm{d}$ from 0 to $164 \mathrm{~g} / \mathrm{d}$ of RP-His and increased to $0.98 \mathrm{~kg} / \mathrm{d}$ with feeding $246 \mathrm{~g} / \mathrm{d}$ of RP-His during wk 4 (quadratic trend; $P=0.07$ ), suggesting that milk protein synthesis was not stimulated by His supply up to $164 \mathrm{~g} / \mathrm{d}$ of RP-His. As discussed above, although our diets had adequate dMet status, they were deficient in dLys and this may have affected milk protein synthesis. Giallongo et al. (2016) observed that supplementation of $120 \mathrm{~g} / \mathrm{d}$ of RP-His did not modify milk true protein yield in dairy cows fed a MP-deficient diet with negative dLys and dMet balances. However, milk true protein increased significantly when RP-Lys, RP-Met, and RP-His were all supplemented to a MP-deficient diet in their experiment (i.e., Giallongo et al., 2016), thereby in agreement with data from Lee at al. (2012). No changes in plasma EAA concentrations apart from His were observed during wk 4 in cows receiving supplemental RP-His in the current study despite the quadratic trend for increased milk true protein yield. Milk yield was moderate in the present study and MP balance was slightly negative so that the EAA requirements for milk protein synthesis were lowered if compared with those of high-producing dairy cows. According to Patton et al. (2015), concentrations of circulating EAA are the product of duodenal flows of EAA, digestibility, and EAA utilization in different tissues. Although EAA can be removed by hepatic (Raggio et al., 2004), peripheral (Dalbach et al., 2011), and mammary tissues (Raggio et al., 2006), Patton et al. (2015) demonstrated that the plasma concentrations of EAA are mostly affected by duodenal flows of AA. Patton et al. (2015) also showed that prediction of plasma AA concentrations was not improved even when expressing supply relative to milk true protein output. They concluded that the plasma concentrations of EAA appear to be tightly controlled elevating steadily in response to increased amounts of EAA reaching the small intestine.

No treatment by week interactions were observed for the plasma and muscle concentrations of His, His-containing dipeptides, and 3-MHis despite some significant week effects. For instance, plasma carnosine concentration did not change from wk 1 to 2 but increased from wk 2 to 4 (Figure 1B), which may be attributed to exportation of carnosine from muscle to blood as discussed in detail above. We also observed that the concentration of 3-MHis in plasma was greatest during wk 2, suggesting increased muscle proteolysis after cows have been on a given diet for about $14 \mathrm{~d}$ (Figure 1C). However, we do not have a definite explanation for this 
change in plasma 3-MHis concentration based on data available. Overall, His deficiency may not have been pronounced enough to trigger major temporal changes in plasma and muscle His and His-derived metabolites in the current study.

\section{CONCLUSIONS}

Our hypothesis that the concentrations of plasma and muscle His would increase linearly in response to incremental amounts of RP-His was confirmed. Furthermore, milk true protein yield tended to increase in a quadratic manner in dairy cows fed increasing levels of RP-His. Specifically, milk true protein yield averaged $0.93 \mathrm{~kg} / \mathrm{d}$ from 0 to $164 \mathrm{~g} / \mathrm{d}$ of RP-His and increased to $0.98 \mathrm{~kg} / \mathrm{d}$ with feeding $246 \mathrm{~g} / \mathrm{d}$ of RP-His. This suggests that milk protein synthesis was not stimulated by His supply up to $164 \mathrm{~g} / \mathrm{d}$ of RP-His (i.e., $10 \mathrm{~g} / \mathrm{d}$ of dHis) under the conditions of the present study. It is important to note that our diets went from slightly adequate to deficient in predicted dLys balance, which may have affected yields of milk and milk true protein despite adequate dMet status. Concentrations of MUN and PUN, as well as urinary excretion of urea- $\mathrm{N}(\mathrm{g} / \mathrm{d}$ and $\%$ of $\mathrm{N}$ intake) and total-N (g/d), increased linearly with the greatest values observed in cows offered 164 or $246 \mathrm{~g}$ of RPHis daily. Intriguingly, the threshold amount of RP-His that stimulated milk protein synthesis (i.e., $\geq 164 \mathrm{~g} / \mathrm{d}$ or $\geq 10 \mathrm{~g} / \mathrm{d}$ of dHis) also led to increased MUN, PUN, and urinary $\mathrm{N}$ excretion. These conflicting results could not be sorted out using our data, so future research is warranted to accurately determine the bioavailability of RP-His supplements and His requirements for milk protein synthesis. Continuous, dose-response production studies are particularly needed to provide further insights regarding His metabolism in high-producing dairy cows.

\section{ACKNOWLEDGMENTS}

Partial funding was provided by the New Hampshire Agricultural Experiment Station (Durham, NH; Scientific Contribution Number 2809). This work was also supported by the USDA-National Institute of Food and Agriculture Hatch Multistate NC-2042 (Project Number NH00616-R; Project Accession Number 1001855). We are grateful to the University of New Hampshire undergraduate students Ashley Bonnette, Marissa Prizio, Jonathan Decker, and Bronte Elias for assistance during feeding and sampling. A special thanks to Jon Whitehouse and his farm crew at the University of New Hampshire Fairchild Teaching and Research Center for research support and excellent animal care.
Gratitude is extended to Dean Elder (University of New Hampshire Animal Resources Office) for performing the muscle biopsies.

\section{REFERENCES}

AOAC. 1990. Official Methods of Analysis. 15th ed. Assoc. Off. Anal. Chem., Arlington, VA.

AOAC International. 2016. Official Methods of Analyses, 20th ed. AOAC International, Gaithersburg, MD.

Boldyrev, A. A., G. Aldini, and W. Derave. 2013. Physiology and pathophysiology of carnosine. Physiol. Rev. 93:1803-1845.

Broderick, G. A. 2003. Effects of varying dietary protein and energy levels on the production of lactating dairy cows. J. Dairy Sci. 86:1370-1381.

Broderick, G. A., M. Stevenson, and R. Patton. 2009. Effect of dietary protein concentration and degradability on response to rumen-protected methionine in lactating dairy cows. J. Dairy Sci. 92:2719-2728.

Chen, X. B., Y. Chen, M. Franklin, E. Orskov, and W. Shand. 1992. The effect of feed intake and body weight on purine derivative excretion and microbial protein supply in sheep. J. Anim. Sci. 70:1534-1542.

Cochran, R., D. Adams, J. Wallace, and M. Galyean. 1986. Predicting digestibility of different diets with internal markers: Evaluation of four potential markers. J. Anim. Sci. 63:1476-1483.

Dalbach, K. F., M. Larsen, B. M. L. Raun, and N. B. Kristensen. 2011. Effects of supplementation with 2-hydroxy-4-(methylthio)butanoic acid isopropyl ester on splanchnic amino acid metabolism and essential amino acid mobilization in postpartum transition Holstein cows. J. Dairy Sci. 94:3913-3927.

Davey, C. L. 1960. The significance of carnosine and anserine in striated skeletal muscle. Arch. Biochem. Biophys. 89:303-308.

de Souza, R. A., R. Tempelman, M. Allen, W. Weiss, J. Bernard, and M. VandeHaar. 2018. Predicting nutrient digestibility in highproducing dairy cows. J. Dairy Sci. 101:1123-1135.

Doepel, L., and H. Lapierre. 2010. Changes in production and mammary metabolism of dairy cows in response to essential and nonessential amino acid infusions. J. Dairy Sci. 93:3264-3274.

Everaert, I., H. De Naeyer, Y. Taes, and W. Derave. 2013. Gene expression of carnosine-related enzymes and transporters in skeletal muscle. Eur. J. Appl. Physiol. 113:1169-1179.

Everaert, I., Y. Taes, E. De Heer, H. Baelde, A. Zutinic, B. Yard, S. Sauerhöfer, L. Vanhee, J. Delanghe, and G. Aldini. 2012. Low plasma carnosinase activity promotes carnosinemia after carnosine ingestion in humans. Am. J. Physiol. Renal Physiol. 302:F1537F1544.

Ferraretto, L. F., and R. Shaver. 2015. Effects of whole-plant corn silage hybrid type on intake, digestion, ruminal fermentation, and lactation performance by dairy cows through a meta-analysis. J. Dairy Sci. 98:2662-2675.

Gaines, W. L., and F. A. Davidson. 1923. Relation between percentage fat content and yield of milk. Bull. 245. Ill. Agric. Expt. Sta., Urbana, IL.

Ghedini, C. P., D. C. Moura, R. A. V. Santana, A. S. Oliveira, and A. F. Brito. 2018. Replacing ground corn with incremental amounts of liquid molasses does not change milk enterolactone but decreases production in dairy cows fed flaxseed meal. J. Dairy Sci. 101:2096-2109.

Giallongo, F., M. Harper, J. Oh, J. Lopes, H. Lapierre, R. Patton, C. Parys, I. Shinzato, and A. Hristov. 2016. Effects of rumen-protected methionine, lysine, and histidine on lactation performance of dairy cows. J. Dairy Sci. 99:4437-4452.

Giallongo, F., M. Harper, J. Oh, C. Parys, I. Shinzato, and A. Hristov. 2017. Histidine deficiency has a negative effect on lactational performance of dairy cows. J. Dairy Sci. 100:2784-2800.

Giallongo, F., A. Hristov, J. Oh, T. Frederick, H. Wk, J. Werner, H. Lapierre, R. Patton, A. Gehman, and C. Parys. 2015. Effects of 
slow-release urea and rumen-protected methionine and histidine on performance of dairy cows. J. Dairy Sci. 98:3292-3308.

Graulet, B., C. Richard, and J. Robert. 2005. Methionine availability in plasma of dairy cows supplemented with methionine hydroxy analog isopropyl ester. J. Dairy Sci. 88:3640-3649.

Hall, M. B., W. H. Hoover, J. P. Jennings, and T. K. M. Webster. 1999. A method for partitioning neutral detergent soluble carbohydrates. J. Sci. Food Agric. 79:2079-2086.

Harris, C., and G. Milne. 1981. The urinary excretion of N-methyl histidine by cattle: Validation as an index of muscle protein breakdown. Br. J. Nutr. 45:411-422.

Harris, R. C., M. Tallon, M. Dunnett, L. Boobis, J. Coakley, H. J. Kim, J. L. Fallowfield, C. Hill, C. Sale, and J. A. Wise. 2006. The absorption of orally supplied $\beta$-alanine and its effect on muscle carnosine synthesis in human vastus lateralis. Amino Acids $30: 279-289$.

Holter, J., J. Byrne, and C. Schwab. 1982. Crude protein for high milk production. J. Dairy Sci. 65:1175-1188.

Houweling, M., S. Van Der Drift, R. Jorritsma, and A. Tielens. 2012. Quantification of plasma 1-and 3-methylhistidine in dairy cows by high-performance liquid chromatography-tandem mass spectrometry. J. Dairy Sci. 95:3125-3130.

Huhtanen, P., K. Kaustell, and S. Jaakkola. 1994. The use of internal markers to predict total digestibility and duodenal flow of nutrients in cattle given six different diets. Anim. Feed Sci. Technol. 48:211-227.

Jackson, M. C., C. M. Kucera, and J. F. Lenney. 1991. Purification and properties of human serum carnosinase. Clin. Chim. Acta 196:193-205.

Kim, B. G., and H. H. Stein. 2009. A spreadsheet program for making a balanced Latin square design. Revista Colombiana de Ciencias Pecuarias 22:591-596.

Kirchofer, K. S., C. R. Calkins, and B. Gwartney. 2002. Fiber-type composition of muscles of the beef chuck and round. J. Anim. Sci. $80: 2872-2878$

Korhonen, M., A. Vanhatalo, T. Varvikko, and P. Huhtanen. 2000. Responses to graded postruminal doses of histidine in dairy cows fed grass silage diets. J. Dairy Sci. 83:2596-2608.

Lapierre, H., D. Ouellet, L. Doepel, G. Holtrop, and G. Lobley. 2008. Histidine, lysine and methionine: From metabolism to balanced dairy rations. Pages 19-36 in Proc. 44th Eastern Nutrition Conference of the Animal Nutrition Association of Canada (ANAC), University of Guelph, Guelph, ON, Canada. University of Guelph, Guelph, ON, Canada.

Lapierre, H., D. Ouellet, and G. Lobley. 2014. Estimation of histidine requirement in lactating dairy cows. J. Dairy Sci. 97:757.

Lee, C., A. Hristov, T. Cassidy, K. Heyler, H. Lapierre, G. Varga, M. De Veth, R. Patton, and C. Parys. 2012. Rumen-protected lysine, methionine, and histidine increase milk protein yield in dairy cows fed a metabolizable protein-deficient diet. J. Dairy Sci. 95:6042-6056

Lee, C., A. Hristov, K. Heyler, T. Cassidy, M. Long, B. Corl, and S. Karnati. 2011. Effects of dietary protein concentration and coconut oil supplementation on nitrogen utilization and production in dairy cows. J. Dairy Sci. 94:5544-5557.

Maynard, L. M., G. A. Boissonneault, C. K. Chow, and G. G. Bruckner. 2001. High levels of dietary carnosine are associated with increased concentrations of carnosine and histidine in rat soleus muscle. J. Nutr. 131:287-290.

Morris, D. L., L. R.. Rebelo, P. A. Dieter, and C. Lee. 2018. Validating intrinsic markers and optimizing spot sampling frequency to estimate fecal outputs. J. Dairy Sci. 101:7980-7989.
NRC. 2001. Nutrient Requirements of Dairy Cattle. 7th ed. Natl Acad. Sci., Washington, DC.

Olmos Colmenero, J., and G. Broderick. 2006. Effect of dietary crude protein concentration on milk production and nitrogen utilization in lactating dairy cows. J. Dairy Sci. 89:1704-1712.

Ouellet, D., G. Lobley, and H. Lapierre. 2014. Histidine requirement of dairy cows determined by the indicator amino acid oxidation (AAO) technique. J. Dairy Sci. 97:757.

Patton, R., A. Hristov, C. Parys, and H. Lapierre. 2015. Relationships between circulating plasma concentrations and duodenal flows of essential amino acids in lactating dairy cows. J. Dairy Sci 98:4707-4734.

Pereira, A. B., N. Whitehouse, K. Aragona, C. Schwab, S. Reis, and A. Brito. 2017. Production and nitrogen utilization in lactating dairy cows fed ground field peas with or without ruminally protected lysine and methionine. J. Dairy Sci. 100:6239-6255.

Raggio, G., S. Lemosquet, G. Lobley, H. Rulquin, and H. Lapierre. 2006. Effect of casein and propionate supply on mammary protein metabolism in lactating dairy cows. J. Dairy Sci. 89:4340-4351.

Ragrio, G., D. Pacheco, R. Berthiaume, G. Lobley, D. Pellerin, G. Allard, P. Dubreuil, and H. Lapierre. 2004. Effect of level of metabolizable protein on splanchnic flux of amino acids in lactating dairy cows. J. Dairy Sci. 87:3461-3472.

Rosenthal, H. L. 1955. Determination of urea in blood and urine with diacetyl monoxime. Anal. Chem. 27:1980-1982.

Sampaio, C. B., E. Detmann, T. N. P. Valente, V. A. C. Costa, S. C. Valadares Filho, and A. C. d. Queiroz. 2011. Fecal excretion patterns and short term bias of internal and external markers in a digestion assay with cattle. Rev. Bras. Zootec. 40:657-665.

Schwab, C. G., L. Satter, and A. Clay. 1976. Response of lactating dairy cows to abomasal infusion of amino acids. J. Dairy Sci 59:1254-1270

Swick, R. W., and N. Benevenga. 1977. Labile protein reserves and protein turnover. J. Dairy Sci. 60:505-515.

Tyrrell, H. F., and J. T. Reid. 1965. Prediction of the energy value of cow's milk. J. Dairy Sci. 48:1215-1223.

Valadares, R. F., G. Broderick, S. Valadares Filho, and M. Clayton. 1999. Effect of replacing alfalfa silage with high moisture corn on ruminal protein synthesis estimated from excretion of total purine derivatives. J. Dairy Sci. 82:2686-2696.

Velásquez, A. V., G. da Silva, D. Sousa, C. Oliveira, C. Martins, P. Dos Santos, J. Balieiro, F. Rennó, and R. Fukushima. 2018. Evaluating internal and external markers versus fecal sampling procedure interactions when estimating intake in dairy cows consuming a corn silage-based diet. J. Dairy Sci. 101:5890-5901.

Whitehouse, N. L., C. G. Schwab, and A. Brito. 2017. The plasma free amino acid dose-response technique: A proposed methodology for determining lysine relative bioavailability of rumen-protected lysine supplements. J. Dairy Sci. 100:9585-9601.

Wildman, E., G. Jones, P. Wagner, R. Boman, H. Troutt, and T. Lesch. 1982. A dairy cow body condition scoring system and its relationship to selected production characteristics. J. Dairy Sci. 65:495-501.

Williams, E. 1949. Experimental designs balanced for the estimation of residual effects of treatments. Aust. J. Chem. 2:149-168.

Zang, Y., S. S. Samii, Z. Phipps, L. Tager, J. McFadden, and K. Krause. 2017. Comparative effects of multiple sources of rumenprotected methionine on milk production and serum amino acid levels in mid-lactation dairy cows. Prof. Anim. Sci. 33:692-699. 